Check for updates

Cite this: RSC Adv., 2018, 8, 22515

Received 7th May 2018

Accepted 9th June 2018

DOI: $10.1039 / c 8 r a 03879 a$

rsc.li/rsc-advances

\section{Synthesis, spectroscopic, thermal, antimicrobial and electrochemical characterization of some novel Ru(III), Pt(IV) and Ir(III) complexes of pipemidic acid}

\author{
Khuloud A. Alibrahim, ${ }^{\text {a }}$ Foziah A. Al-Saif, ${ }^{\text {a }}$ M. T. Alghamdi, ${ }^{\text {b }}$ M. S. El-Shahawi, (D) bc \\ Y. M. Moustafa ${ }^{d}$ and Moamen S. Refat (D) *ef
}

Three new solid complexes of pipemidic acid (Pip-H) with $\mathrm{Ru}^{3+}, \mathrm{Pt}^{4+}$ and $\mathrm{Ir}^{3+}$ were synthesized and characterized. Pipemidic acid acts as a uni-dentate chelator through the nitrogen atom of the $-\mathrm{NH}$ piperazyl ring. The spectroscopic data revealed that the general formulas of Pip- $\mathrm{H}$ complexes are $\left[\mathrm{M}(\mathrm{L})_{n}(\mathrm{Cl})_{x}\right] \cdot y \mathrm{H}_{2} \mathrm{O}\left((1) \mathrm{M}=\mathrm{Ru}^{3+}, \mathrm{L}: \mathrm{Pip}-\mathrm{H}, n=3, x=3, y=6\right.$; (2) $\mathrm{M}=\mathrm{Pt}^{4+}$, L: Pip $-\mathrm{NH}_{4}, n=2, x=4, y=$ 0 and (3) $M=1 r^{3+}, \mathrm{L}: \mathrm{Pip}-\mathrm{H}, n=3, x=3, y=6$ ). The number of water molecules with their locations inside or outside the coordination sphere were assigned via thermal analyses (TG, DTG). The DTG curves refer to 2-3 thermal decomposition steps where the first decomposition step at a lower temperature corresponds to the loss of uncoordinated water molecules followed by the decomposition of Pip-H molecules at higher temperatures. Thermodynamic parameters ( $E^{*}, \Delta S^{*}, \Delta H^{*}$ and $\Delta G^{*}$ ) were calculated from the TG curves using Coats-Redfern and Horowitz-Metzeger non-isothermal models. X-ray powder diffraction (XRD), scanning electron microscopy (SEM) and transmission electron microscopy (TEM) techniques were carefully used to assign properly the particle sizes of the prepared Pip-H complexes. The biological enhancement of Pip-H complexes rather than free chelate were assessed in vitro against four kinds of bacteria $\mathrm{G}(+)$ (Staphylococcus epidermidis and Staphylococcus aureus) and G(-) (Klebsiella and Escherichia coli) as well as against the human breast cancer (MCF-7) tumor cell line.

\section{Introduction}

Pipemidic acid (Pip-H; Fig. 1) has the IUPAC formula 8-ethyl5,8-dihydro-5-oxo-2-(1-piperazinyl)-pyrido[2,3- $d]$ pyrimidine-6carboxylic acid. ${ }^{1}$ Pip-H has medical efficacy in the treatment of urinary tract infections because of its antibacterial agency against Gram-negative and some Gram-positive bacteria. ${ }^{2}$ Concerning the Pip- $\mathrm{H}$ moiety, the $-\mathrm{COOH}$ group existing at the $\mathrm{C}_{6}$-position gives this drug an acidic nature, while the piperazine ring in the $\mathrm{C}_{2}$-position includes an $-\mathrm{NH}$ group that is basic in character. In aqueous media solution, 2-piperazinyl quinolone exists in three different species: acidic for $\mathrm{pH}$ values below $\mathrm{p} K_{\mathrm{a}_{1}}=5.4$, neutral for $\mathrm{pH}$ values close to the

${ }^{a}$ College of Science, Princess Nourah bint Abdulrahman University, Department of Chemistry, Kingdom of Saudi Arabia

${ }^{b}$ Department of Chemistry, Faculty of Science, King Abdulaziz University, Jeddah, P. O. Box 80203, Saudi Arabia

'Department of Chemistry, Faculty of Science, Damiatta University, Damiatta, Egypt ${ }^{d}$ Faculty of Applied Science, Umm Al-Qura University, P. O. Box 16722, Makkah 21955, Saudi Arabia

${ }^{e}$ Department of Chemistry, Faculty of Science, Taif University, Al-Hawiah, P. O. Box 888 Zip Code 21974, Taif, Saudi Arabia. E-mail: msrefat@yahoo.com

${ }^{f}$ Department of Chemistry, Faculty of Science, Port Said University, Port Said, Egypt isoelectric point $(\mathrm{pH}=6.8)$ and alkaline for $\mathrm{pH}$ values higher than $\mathrm{p} K_{\mathrm{a}_{2}}=8.2 .^{3}$ The Pip-H antibiotic drug is important as an antibacterial agent against Pseudomonas aeruginosa. ${ }^{4}$ It robustly damages DNA in the absence of an exogenous metabolizing system and it can act as a multi-dentate chelator, binding with metal ions. ${ }^{5}$

Quinolone-metal chelates have the potential ability to interact with various metal ions and record biological activity towards different microorganisms. ${ }^{6,7}$ Quinolones can be act as uni-dentate, bi-dentate and bridging chelates. In general, quinolones are coordinated in bi-dentate fashion, and this takes place through one oxygen atom upon deprotonation of the $-\mathrm{COOH}$ group and carbonyl oxygen atom (Fig. 2a). Rarely,

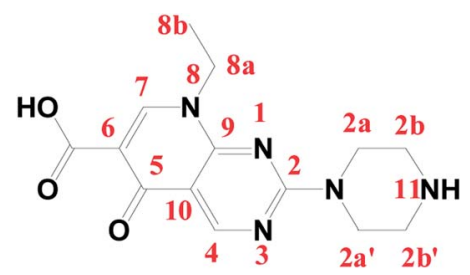

Fig. 1 Structure and numbering of the pipemidic acid (Pip-H) antibiotic drug. 


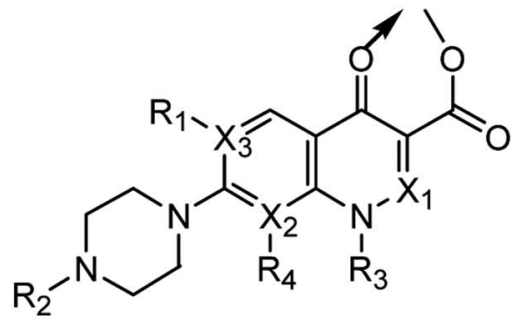

a

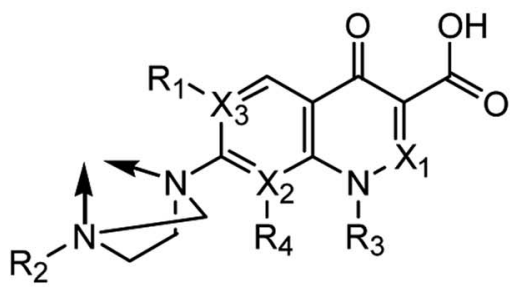

c<smiles>[R][Y4]1=Cc2c([Y4]([R4])cc(C(=O)OC)c2=O)N([R3])[Y4]1=C(C)OC</smiles>

b<smiles></smiles>

Fig. $2(a-d)$ Chelation modes of quinolone drugs towards metal ions.

quinolones can act as bi-dentate chelators via two carboxyl oxygen atoms (Fig. 2b) or through both piperazinic nitrogen atoms (Fig. 2c). Quinolones can also form complexes via unidentate ligand binding to the metal ion through the terminal piperazinyl nitrogen (Fig. $2 \mathrm{~d}$ ). ${ }^{8}$

The medicinal usage of platinum(II,IV) compounds was limited by the development of tumor resistance to the drugs ${ }^{9}$ and by their side effects. ${ }^{10}$ These limitations caused further research to be oriented toward finding new, more active, less toxic, anti-tumor agents based on other chelates. Ruthenium(III) complexes had shown ligand exchange kinetics similar to those of the platinum anti-tumor agents currently used in the clinic and exhibited a reduced toxicity. ${ }^{11}$ The interactions of different metal ions with pipemidic acid as an antimicrobial agent have been discussed ${ }^{12}$ and can be referenced by chemical formulas with different molar ratios between Pip- $\mathrm{H}$ and some metal ions as follows (Table 1):

Metal ions are considered essential to the human body, being an integral part of organic moieties in performing actions of physiological interest and having vital properties in the body. ${ }^{13}$ The synthesis and assignment of new metal complexes with quinolones are of wide importance for a better understanding of drug-metal interactions. ${ }^{14}$ Complexes of quinolone drugs and metal ions are synthesized with different chemical structures and different types of chelation, ${ }^{15,16}$ so, this article refers to the synthesis and spectroscopic characterizations of a new complexation mode between ruthenium(III), platinum(IV) and iridium(III) metal ions with the Pip-H drug as a $1^{\text {st }}$ generation of quinolone antibacterial drugs. The new complexes were synthesized in $\mathrm{CH}_{3} \mathrm{OH}$ solvent with ratios of $1: 3$ and $1: 2$. These complexes have been interpreted using micro-analytical, FT-IR, conductance, magnetic, UV-vis, ${ }^{1} \mathrm{H}-\mathrm{NMR}$ and TG-DTG analyses. The morphological surface and particle size of these three new complexes were investigated using XRD, SEM and TEM.

\section{Experimental}

\subsection{Chemical materials}

Pipemidic acid (Pip-H) was purchased from the Aldrich-Sigma Chemical Company. $\mathrm{RuCl}_{3}, \mathrm{H}_{2} \mathrm{PtCl}_{6} \cdot 6 \mathrm{H}_{2} \mathrm{O}$ and $\mathrm{IrCl}_{3} \cdot x \mathrm{H}_{2} \mathrm{O}$ and solvents like $\mathrm{CH}_{3} \mathrm{OH}$ and dimethylsulfoxide (DMSO) were purchased from the Fluka Chemical Company and used without further purification. Tetrabutylammonium perchlorate (TBAP) (Sigma-Aldrich) was used as supporting electrolyte at various scan rates $\left(50-2000 \mathrm{mV} \mathrm{s}^{-1}\right)$.

\subsection{Synthesis of pipemidic acid complexes}

A hot methanolic solution ( $3 \mathrm{mmol}, 20 \mathrm{~mL}$ ) of pipemidic acid $(91 \mathrm{mg})$ was added to an aqueous solution $(20 \mathrm{~mL})$ of $\mathrm{RuCl}_{3}$

Table 1 Different Pip-H complexes with different metal ions, chemical formulas and molar ratios

\begin{tabular}{lll}
\hline & Molar ratio & Formula \\
\hline Pip-H complexes & $1: 1$ & {$\left[\mathrm{Fe}(\mathrm{PPA})(\mathrm{HO})_{2}\left(\mathrm{H}_{2} \mathrm{O}\right)\right]$} \\
$1: 2$ & {$\left[\mathrm{VO}(\mathrm{PPA})_{2}\left(\mathrm{H}_{2} \mathrm{O}\right)\right],\left[\mathrm{Mn}(\mathrm{PPA})_{2}\left(\mathrm{H}_{2} \mathrm{O}\right)_{2}\right],\left[\mathrm{Co}(\mathrm{PPA})_{2}\left(\mathrm{H}_{2} \mathrm{O}\right)_{2}\right]$,} \\
& {$\left[\mathrm{Ni}(\mathrm{PPA})_{2}\left(\mathrm{H}_{2} \mathrm{O}\right)_{2}\right],\left[\mathrm{Zn}(\mathrm{PPA})_{2}\left(\mathrm{H}_{2} \mathrm{O}\right)_{2}\right],\left[\mathrm{MoO} \mathrm{O}_{2}(\mathrm{PPA})_{2}\right]$,} \\
& {$\left[\mathrm{Cd}(\mathrm{PPA})_{2}\left(\mathrm{H}_{2} \mathrm{O}\right)_{2}\right],\left[\mathrm{UO} \mathrm{U}_{2}(\mathrm{PPA})_{2}\right],\left[\mathrm{Cu}(\mathrm{PPA})_{2}\left(\mathrm{H}_{2} \mathrm{O}\right)\right]$}
\end{tabular}


(1 mmol, $20.8 \mathrm{mg}$ ) and $\mathrm{IrCl}_{3} \cdot x \mathrm{H}_{2} \mathrm{O}(1 \mathrm{mmol}, 29.9 \mathrm{mg})$. The reaction mixtures were refluxed for $1-2 \mathrm{~h}$ at $\sim 70-80{ }^{\circ} \mathrm{C}$. The solutions were filtered off and left to slowly evaporate. After a day a black-dark green microcrystalline product was deposited, collected by filtration, washed with methanol and dried under vacuum. The same procedure was repeated for the platinum(Iv) complex with a molar ratio $1: 2$ of $\mathrm{H}_{2} \mathrm{PtCl}_{6} \cdot 6 \mathrm{H}_{2} \mathrm{O}$ ( $1 \mathrm{mmol}, 51.8 \mathrm{mg}$ ) and Pip-H (2 mmol, $60.7 \mathrm{mg})$. However, then an aliquot of aqueous ammonia was added to $\mathrm{Pip}-\mathrm{H} / \mathrm{H}_{2} \mathrm{PtCl}_{6}$ $\cdot 6 \mathrm{H}_{2} \mathrm{O}$ and an ammonia-based complex was consequently formed.

$\left[\mathrm{Ru}(\mathrm{Pip}-\mathrm{H})_{3}(\mathrm{Cl})_{3}\right] \cdot \mathbf{6 H}_{2} \mathrm{O}$ complex (1). Yield: $96.15 \mathrm{mg}, 86 \%$. Anal calc. for complex (1) $\left(\mathrm{C}_{42} \mathrm{H}_{63} \mathrm{Cl}_{3} \mathrm{~N}_{15} \mathrm{O}_{15} \mathrm{Ru}\right)(\mathrm{MW}=$ $1225.47 \mathrm{~g} \mathrm{~mol}^{-1}$ ): calcd: C, 41.16; H, 5.18; N, 17.14; Ru, 8.25. Found: C, 41.04; H, 5.09; N, 17.12; Ru, 8.19\%. The complex is black in color, soluble in (DMSO and DMF) and is a nonelectrolyte $(0.022 \mathrm{mS})$.

[Pt(Pip- $\left.\left.\mathbf{N H}_{4}\right)_{2}(\mathbf{C l})_{4}\right]$ complex (2). Yield: $90 \mathrm{mg}, 80 \%$. Anal calc. for complex (2) $\left(\mathrm{C}_{28} \mathrm{H}_{40} \mathrm{C}_{14} \mathrm{~N}_{12} \mathrm{O}_{6} \mathrm{Pt}\right)(\mathrm{MW}=977.58 \mathrm{~g}$ $\mathrm{mol}^{-1}$ ): calcd: C, 34.40; H, 4.12; N, 17.19; Pt, 19.96. Found: C, 34.22; H, 4.06; N, 17.06; Pt, 19.90\%. The complex is dark green, soluble in (DMSO and DMF) and is a non-electrolyte $(0.042 \mathrm{mS})$.

$\left[\operatorname{Ir}(\mathbf{P i p}-\mathbf{H})_{3}(\mathbf{C l})_{3}\right] \cdot \mathbf{6 H}_{2} \mathbf{O}$ complex (3). Yield: $100.35 \mathrm{mg}, 83 \%$. Anal calc. for complex (3) $\left(\mathrm{C}_{42} \mathrm{H}_{63} \mathrm{Cl}_{3} \mathrm{IrN}_{15} \mathrm{O}_{15}\right)(\mathrm{MW}=1316.62 \mathrm{~g}$ $\mathrm{mol}^{-1}$ ): calcd: $\mathrm{C}, 38.31 ; \mathrm{H}, 4.82 ; \mathrm{N}, 15.96 ; \mathrm{Ir}, 14.60$. Found: C, $38.29 ; \mathrm{H}, 4.57$; N, 15.92; Ir, 14.55\%. The complex is dark green in color, soluble in (DMSO and DMF) and is a non-electrolyte $(0.011 \mathrm{mS})$.

\subsection{Instrumentation and analytical measurements}

The micro-analytical analyses of $\% \mathrm{C}, \% \mathrm{H}$ and $\% \mathrm{~N}$ were made using a PerkinElmer CHN 2400 instrument (USA). Metal contents $(\%)$ were determined by conventional gravimetric analysis methods as the stable metal oxides $\mathrm{MO}_{2}$ formed. A Jenway 4010 conductivity meter was used for recording the molar conductivities of the complexes $\left(1.0 \times 10^{-3} \mathrm{~mol} \mathrm{~cm}^{-3}\right)$ in DMSO. A UV2-Unicam UV/vis spectrophotometer fitted with a quartz cell of $1.0 \mathrm{~cm}$ path length was used for recording the electronic spectra of the prepared metal complexes. Infrared spectra with $\mathrm{KBr}$ discs were recorded on a Bruker FT-IR Spectrophotometer (4000-400 $\left.\mathrm{cm}^{-1}\right)$. Cyclic voltammetric measurements were carried out using an Autolab potentiostat PGSTAT 302 (Eco Chemie, Utrecht, The Netherlands) driven by General Purpose Electrochemical Systems data processing software (GPES, software version 4.9, Eco Chemie). A threecompartment electrochemical cell was used with Pt wires as the working and counter electrodes and $\mathrm{Ag} / \mathrm{AgCl}$ as the reference electrode. The electrochemical experiments were performed in DMS-TBAP (tetrabutylammonium perchlorate). A Shimadzu thermogravimetric analyzer under $\mathrm{N}_{2}$ at $800{ }^{\circ} \mathrm{C}$ was used for recording thermal measurements (TG/DTG-50H) using a single loose top-loading platinum sample pan under nitrogen atmosphere at $30 \mathrm{~mL} \min ^{-1}$ flow rate and a $10{ }^{\circ} \mathrm{C} \min ^{-1}$ heating rate in the temperature range $25-800{ }^{\circ} \mathrm{C}$. ${ }^{1} \mathrm{H}-\mathrm{NMR}$ spectra were recorded in DMSO solution on a Bruker $600 \mathrm{MHz}$ spectrometer using TMS as the internal standard. A
Jeol Jem-1200 EX II scanning electron microscope (SEM) at an acceleration voltage of $25 \mathrm{kV}$ was used for recording the SEM images of the complexes. An X Pert Philips X-ray diffractometer was used for recording X-ray diffraction (XRD) patterns of the samples using $\mathrm{CuK}_{\alpha 1}$ radiation, with a graphite monochromator at $0.02^{\circ} \mathrm{min}^{-1}$ scanning rate. Transmission electron microscopy (TEM) images were performed on a JEOL $100 \mathrm{~s}$ microscope. The mass susceptibility $\left(X_{\mathrm{g}}\right)$ of the complexes was measured at room temperature using a Gouy magnetic balance. The effective magnetic moment $\left(\mu_{\text {eff }}\right)$ value was measured as reported earlier. ${ }^{\mathbf{1 7}}$

\subsection{Molecular modeling studies}

The calculations of quantum chemical and molecular modeling studies for the Pip-H drug chelate are useful to support the suggested structures. ${ }^{18}$ The geometrical optimization and conformational analysis were performed using semi-empirical PM3 level ${ }^{19}$ as implemented in the software of the HyperChem 7.5 program $^{20}$ (Fig. 3 and Table 2). A number of quantum chemical parameters have been estimated: ${ }^{\mathbf{1 8 , 1 9}}$ the highest occupied molecular orbital energy $\left(E_{\text {HOMO }}\right)$, the lowest unoccupied molecular orbital energy ( $\left.E_{\text {LUMO }}\right)$, the difference between the HOMO and LUMO energy levels $(\Delta E)$, Mulliken electronegativity $(\chi)$, chemical potential $\left(P_{\mathrm{i}}\right)$, global hardness $(\eta)$, global softness $(S)$, global electrophilicity $(\omega)$, absolute softness $(\sigma)$ and electronic charge $\left(\Delta N_{\max }\right)$. The high value of the energy gap $(\Delta E)$ led to hard molecules as well as low reactivity, but, the low energy gap data led to soft molecules, with more reactivity and

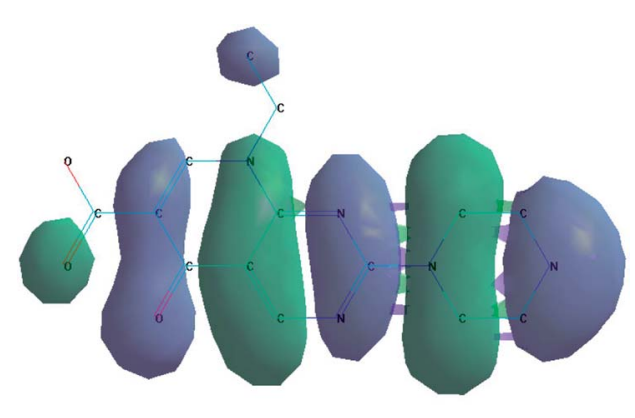

$\mathrm{HOMO}=-3.2798 \mathrm{eV}$

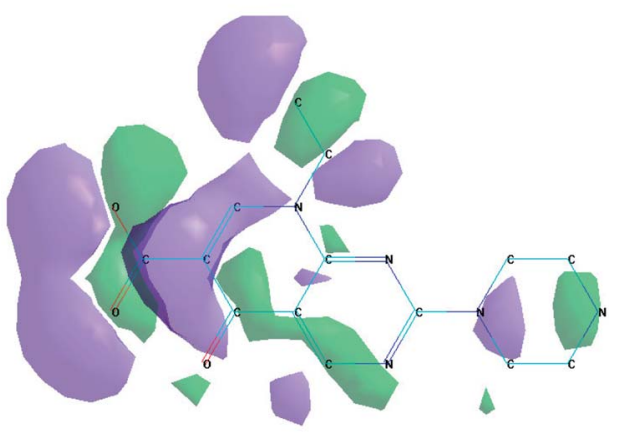

$\mathrm{LUMO}=1.0079 \mathrm{eV}$

Fig. $3 \mathrm{HOMO}$ and LUMO structure of Pip-H free drug. 
Table 2 The quantum chemical parameters of Pip-H drug chelate

\begin{tabular}{l}
\hline Parameters \\
\hline Total energy (a.u) \\
Binding energy (a.u) \\
Heat formation (a.u) \\
Electronic energy (a.u) \\
Dipole moment (debye) \\
$E_{\mathrm{HOMO}}(\mathrm{eV})$ \\
$E_{\mathrm{LUMO}}(\mathrm{eV})$ \\
$\Delta E(\mathrm{eV})$ \\
$\chi(\mathrm{eV})$ \\
$\eta(\mathrm{eV})$ \\
$\sigma(\mathrm{eV})$ \\
$P_{\mathrm{i}}(\mathrm{eV})$ \\
$S(\mathrm{eV})$ \\
$\omega(\mathrm{eV})$ \\
$\Delta N_{\max }(\mathrm{eV})$
\end{tabular}
Pip-H 164.3 282.4 287.4 $-948.1$ 568.30 $-3.279$ 1.0078 4.2876 1.1359 2.1438 0.4665 $-1.136$ 0.2332 0.3009 0.5299

highly flexible transfer of electrons from the donor (ligand) to the acceptors (metal ions). Lower values of $E_{\text {LuMo gave high }}$ acceptability for electrons, ${ }^{19}$ and high values of $E_{\text {Hомо }}$ allowed electrons to be easily liberated. High values of $E_{\text {Hомо }}$ confirmed that the Pip-H ligand has powerful donation behavior. The difference between the energy gaps for the ligands reflects the presence of a complexation status. The global electrophilicity $(\omega)$ of Pip-H increases to that attributed to the highest capacity of accepted electrons. The calculation of both global hardness $(\eta)$ and absolute softness $(\sigma)$ parameters is useful for recognizing their molecular stability and reactivity. The negative data for both $E_{\mathrm{LUMO}}$ and $E_{\mathrm{HOMO}}$ were assigned to the stability of the synthetic complexes.

\subsection{Biological experiments}

In accordance with Gupta et al. ${ }^{21}$ the hole well method was applied. The investigated isolates of the bacteria were seeded in tubes with a nutrient broth (NB). The seeded NB $\left(1 \mathrm{~cm}^{3}\right)$ was homogenized in the tubes with $9 \mathrm{~cm}^{3}$ of melted $\left(45^{\circ} \mathrm{C}\right)$ nutrient agar (NA). The homogeneous suspensions were poured into Petri dishes. Holes (diameter $4 \mathrm{~mm}$ ) were made in the cooled medium. After cooling in these holes, $2 \times 10^{-3} \mathrm{dm}^{3}$ of the investigated compounds were applied using a micropipette. After incubation for $24 \mathrm{~h}$ in a thermostat at $25-27{ }^{\circ} \mathrm{C}$, the inhibition (sterile) zone diameters (including the disc) were measured and expressed in $\mathrm{mm}$. An inhibition zone diameter over $7 \mathrm{~mm}$ indicates that the tested compound is active against the bacteria under investigation. The antibacterial activities of the investigated complexes were tested against bacteria $\mathrm{G}(+)$ (Staphylococcus epidermidis and Staphylococcus aureus) and G(-) (Klebsiella and Escherichia coli).

Mammalian cell lines: MCF-7 cells (human breast cancer cell line) were obtained from VACSERA Tissue Culture Unit. Chemicals used: dimethyl sulfoxide (DMSO), crystal violet and trypan blue dye were purchased from Sigma (St. Louis, Mo., USA). Fetal bovine serum, DMEM, RPMI-1640, HEPES buffer solution, L-glutamine, gentamycin and $0.25 \%$ trypsin-EDTA were purchased from Lonza. Crystal violet stain (1\%): composed of $0.5 \%(\mathrm{w} / \mathrm{v})$ crystal violet and $50 \%$ methanol made up to volume with $\mathrm{dd}_{2} \mathrm{O}$ and filtered through a Whatman no. 1 filter paper.

The cells were propagated in Dulbecco's Modified Eagle's Medium (DMEM) supplemented with 10\% heat-inactivated fetal bovine serum, 1\% L-glutamine, HEPES buffer and $50 \mu \mathrm{g}$ $\mathrm{ml}^{-1}$ gentamycin. All cells were maintained at $37{ }^{\circ} \mathrm{C}$ in a humidified atmosphere with $5 \% \mathrm{CO}_{2}$ and were subcultured twice a week. Cytotoxicity evaluation was undertaken using viability assay: for the cytotoxicity assay, the cells were seeded in a 96-well plate at a cell concentration of $1 \times 10^{4}$ cells per well in $100 \mu \mathrm{L}$ of growth medium. Fresh medium containing different concentrations of the test sample was added after $24 \mathrm{~h}$ of seeding. Serial two-fold dilutions of the tested chemical compound were added to confluent cell monolayers, dispensed into 96-well, flat-bottomed microtiter plates (Falcon, NJ, USA) using a multichannel pipette. The microtiter plates were incubated at $37{ }^{\circ} \mathrm{C}$ in a humidified incubator with $5 \% \mathrm{CO}_{2}$ for a period of $48 \mathrm{~h}$. Three wells were used for each concentration of the test sample. Control cells were incubated without test sample and with or without DMSO. The small percentage of DMSO present in the wells (maximum $0.1 \%$ ) was found not to affect the experiment. After incubation of the cells at $37{ }^{\circ} \mathrm{C}$, various concentrations of sample were added, the incubation was continued for $24 \mathrm{~h}$, and the yield of viable cells was determined by a colorimetric method. In brief, after the end of the incubation period, media were aspirated and the crystal violet solution (1\%) was added to each well for at least 30 minutes. The stain was removed and the plates were rinsed using tap water until all the excess stain had been removed. Glacial acetic acid $(30 \%)$ was then added to all the wells and mixed thoroughly, and then the absorbance of the plates was measured after gentle shaking on a microplate reader (TECAN, Inc.), using a test wavelength of $490 \mathrm{~nm}$. All the results were corrected for background absorbance detected in wells without added stain. Treated samples were compared with the cell control in the absence of the tested compounds. All experiments were carried out in triplicate. The cell cytotoxic effect of each tested compound was calculated. The optical density was measured with a microplate reader (SunRise, TECAN, Inc, USA) to determine the number of viable cells and the percentage viability was calculated as $[(\mathrm{ODt} / \mathrm{ODc})] \times 100 \%$ where $\mathrm{ODt}$ is the mean optical density of wells treated with the tested sample and ODc is the mean optical density of untreated cells. The relation between surviving cells and drug concentration is plotted to get the survival curve of each tumor cell line after treatment with the specified compound. The $50 \%$ inhibitory concentration $\left(\mathrm{IC}_{50}\right)$, the concentration required to cause toxic effects in $50 \%$ of intact cells, was estimated from graphic plots of the dose response curve for each concentration using Graphpad Prism software (San Diego, CA. USA). ${ }^{22,23}$

\section{Results and discussion}

\subsection{Micro-analytical and conductance measurements}

This work aimed to synthesise, and make chemical and electrochemical characterizations of $\mathrm{Ru}(\mathrm{III}), \mathrm{Pt}(\mathrm{IV})$ and $\operatorname{Ir}(\mathrm{III})$ 

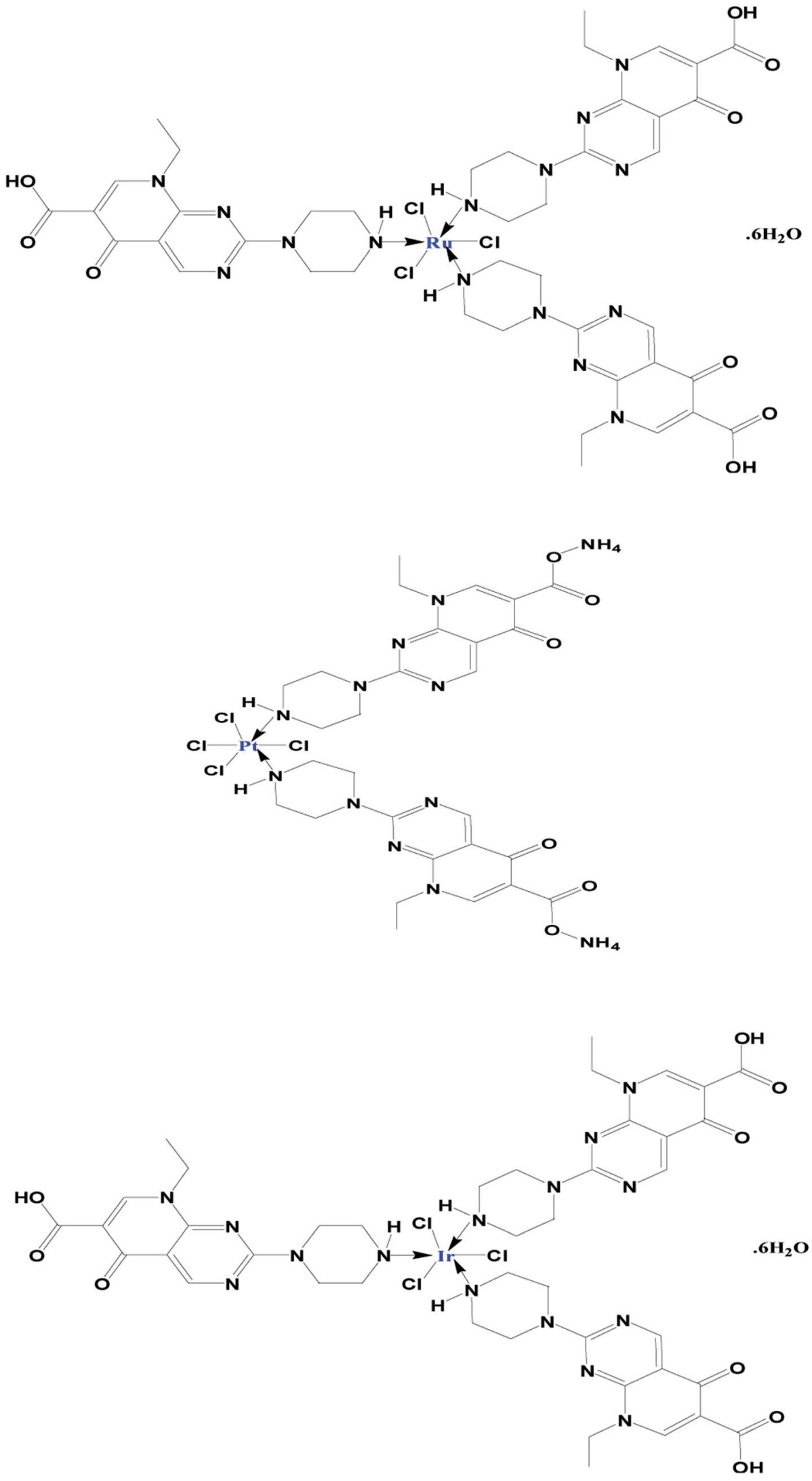

Fig. 4 Proposed chemical structures of the prepared Ru(III), Pt(IV) and Ir(III) Pip-H complexes 1-3. 
complexes with pipemidic acid as a first generation of quinolone drugs. The main target of this study was to identify the chelation mode under the influence of mixed solvent $\mathrm{CH}_{3} \mathrm{OH} /$ $\mathrm{H}_{2} \mathrm{O}(50 / 10 \mathrm{v} / \mathrm{v})$. The percentages of essential elements $(\mathrm{C}, \mathrm{H}$, and $\mathrm{N}$ ) are in agreement with the general formulas of three new Pip- $\mathrm{H}$ complexes as $\left[\mathrm{M}(\mathrm{L})_{n}(\mathrm{Cl})_{x}\right] \cdot y \mathrm{H}_{2} \mathrm{O}\left((\mathbf{1}) \mathrm{M}=\mathrm{Ru}^{3+}, \mathrm{L}\right.$ : Pip- $\mathrm{H}, n$ $=3, x=3, y=6$; (2) $\mathrm{M}=\mathrm{Pt}^{4+}$, L: $\mathrm{Pip}^{-\mathrm{NH}_{4}}, n=2, x=4, y=0$ and (3) $\mathrm{M}=\mathrm{Ir}^{3+}$, L: Pip-H, $n=3, x=3, y=6$ ) (Fig. 4). The Pip-H complexes are stable in air and have high melting points above $250{ }^{\circ} \mathrm{C}$. The conductance data of complexes 1-3 is within the range for non-electrolytic nature $(0.022-0.110 \mathrm{mS})$ with a low limit comparable with electrolyte materials as a ref. 24. From the conductance values it is deduced that the chlorine atoms are exhibited inside the chelation sphere.

\subsection{Infrared spectra}

The FT-IR spectra of Ru(III), Pt(Iv) and Ir(III) Pip-H complexes 1-3 were compared with free Pip-H in order to discuss the coordination modes in three different $\mathrm{Ru}^{3+}, \mathrm{Pt}^{4+}$ and $\mathrm{Ir}^{3+}$ metal ions (Table 3). The FT-IR spectrum of free Pip-H drug does not have a characteristic stretching vibration band $\nu(\mathrm{C}=\mathrm{O})_{\mathrm{COOH}}$ at wavenumber $\sim 1700 \mathrm{~cm}^{-1}$, because the carboxylic group is deprotonated and present in the zwitterionic state..$^{25,26}$ The other distinguishable bands, which exist at 2971 and $1640 \mathrm{~cm}^{-1}$, can be assigned to the stretching vibrations of $\nu(\mathrm{N}-\mathrm{H})_{\text {piperazyl }}$, and $\nu(\mathrm{C}=$ $\mathrm{O})_{\text {pyridine, }}{ }^{25}$ respectively. An $\mathrm{N}-\mathrm{H}$ bond is less polar than an $\mathrm{O}-\mathrm{H}$ bond because nitrogen is less electronegative than oxygen. From this, the $\mathrm{N}-\mathrm{H}$ stretch is less intense, and the peak narrower because the hydrogen bonding is not as strong. After chelation towards $\mathrm{Ru}^{3+}, \mathrm{Pt}^{4+}$ and $\mathrm{Ir}^{3+}$ metal ions (complexes 1-3), the $\nu(\mathrm{N}-$

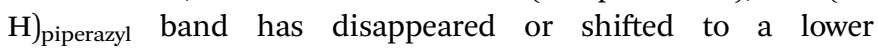

wavenumber $\left(\sim 2930 \mathrm{~cm}^{-1}\right)$, the characteristic band at 1613$1624 \mathrm{~cm}^{-1}$ due to $\nu(\mathrm{C}=\mathrm{O})_{\mathrm{COOH}}$ has still not shifted and the stretching vibration band of $\nu(\mathrm{C}=\mathrm{O})_{\text {pyridone }}$ has shifted to a higher wavenumber $1723-1731 \mathrm{~cm}^{-1}$ compared with free Pip-H $\left(1640 \mathrm{~cm}^{-1}\right)$. These assignments mean that the Pip-H drug acts as a uni-dentate chelator through the nitrogen atom of the piperazyl ring. The new absorption bands present within the range of $2720-2472 \mathrm{~cm}^{-1}$ are assigned to the stretching vibrations of crystallization water molecules under the effects of hydrogen bonds. Since the $\nu(\mathrm{O}-\mathrm{H})_{\mathrm{COOH}}$ vibration changes little, it can be inferred that there is no coordination between the metal ions and the oxygen atoms. The $\mathrm{O}-\mathrm{H}$ stretch of a carboxylic acid is also broadened by hydrogen bonding and it is associated with two characteristic infrared stretching absorptions which change markedly with hydrogen bonding. The assignments of the other stretching vibration motions $\nu(\mathrm{M}-\mathrm{N})$ in $\mathrm{Ru}(\mathrm{III}), \mathrm{Pt}(\mathrm{IV})$ and $\operatorname{Ir}(\mathrm{III})$ Pip- $\mathrm{H}$ complexes 1-3 are observed at $500-400 \mathrm{~cm}^{-1}{ }^{26}$

\subsection{Magnetic measurements and electronic spectra}

The electronic UV-vis. spectra of Pip-H free drugs and their $\mathrm{Ru}^{3+}, \mathrm{Pt}^{4+}$ and $\mathrm{Ir}^{3+}$ complexes 1-3 at a concentration of $10^{-3} \mathrm{M}$ in DMF solvent in the 800-200 $\mathrm{nm}$ range were scanned. These spectra of three new Pip-H complexes have some distinguishable bands within two regions at 280-350 $\mathrm{nm}$ and 350-390 $\mathrm{nm}$. The first range may be assigned to the $\pi \rightarrow \pi^{*}$ electronic transition for the aromatic hydrocarbon rings and the second range includes some electronic absorption bands which may be attributed to the $\mathrm{n} \rightarrow \pi^{*}$ transition for the ketonic, $-\mathrm{NH}$ imine and carboxylic groups, respectively. ${ }^{27}$ In a solid sample, the electronic spectral values of the ruthenium(III) Pip-H complex are listed in Table 4 . The ground state of $\mathrm{Ru}(\mathrm{III})$ is ${ }^{2} \mathrm{~T}_{2 \mathrm{~g}}$ and the

Table 3 FT-IR assignments of $\mathrm{Ru}^{3+}, \mathrm{Pt}^{4+}$ and $\mathrm{Ir}^{3+}-\mathrm{Pip}-\mathrm{H}$ complexes 1-3

\begin{tabular}{llllll}
\hline & \multicolumn{2}{l}{ Assignments $\left(\mathrm{cm}^{-1}\right)$} & & \\
\cline { 2 - 6 } Compounds & $\nu(\mathrm{O}-\mathrm{H})_{\mathrm{COOH}}$ & $\nu(\mathrm{C}=\mathrm{O})_{\mathrm{COOH}}$ & $\nu(\mathrm{C}=\mathrm{O})_{\text {pyridone }}$ & $\delta(\mathrm{C}-\mathrm{H})_{\text {aromatic }}$ \\
\hline Pip-H & 3459 & 1617 & 1640 & 890 & 2912 \\
Complex 1 & 3430 & 1617 & 1728 & 906 & 2971 \\
Complex 2 & 3424 & 1613 & 1731 & 918
\end{tabular}

Table 4 Electronic spectral bands $\left(\mathrm{cm}^{-1}\right)$ and ligand field parameters of the Pip- $\mathrm{H}$ complexes

\begin{tabular}{|c|c|c|c|c|c|c|c|}
\hline Complex & $\lambda_{\max }\left(\mathrm{cm}^{-1}\right)$ & Assignments & $\nu 2 / \nu 1$ & 10Dq $\left(\mathrm{cm}^{-1}\right)$ & $B\left(\mathrm{~cm}^{-1}\right)$ & $C\left(\mathrm{~cm}^{-1}\right)$ & $\beta$ \\
\hline 1 & $\begin{array}{l}13568 \\
19048 \\
22124\end{array}$ & $\begin{array}{l}{ }^{2} \mathbf{T}_{2 g} \rightarrow{ }^{4} \mathbf{T}_{1 g}(\nu 1) \\
{ }^{2} \mathbf{T}_{2 g} \rightarrow{ }^{4} \mathbf{T}_{2 g}(\nu 2) \\
{ }^{2} \mathbf{T}_{2 g} \rightarrow{ }^{2} \mathbf{A}_{2 g},{ }^{2} \mathbf{T}_{1 g}(\nu 3)\end{array}$ & 1.40 & 25661 & 685 & 2167 & 1.08 \\
\hline 2 & $\begin{array}{l}30675 \\
28249 \\
26738 \\
25707\end{array}$ & $\begin{array}{l}{ }^{1} \mathrm{~A}_{1 \mathrm{~g}} \rightarrow{ }^{3} \mathrm{~T}_{1 \mathrm{~g}} \\
{ }^{1} \mathrm{~A}_{1 \mathrm{~g}} \rightarrow{ }^{3} \mathrm{~T}_{2 \mathrm{~g}} \\
{ }^{1} \mathrm{~A}_{1 \mathrm{~g}} \rightarrow{ }^{1} \mathrm{~T}_{1 \mathrm{~g}} \\
{ }^{1} \mathrm{~A}_{1 \mathrm{~g}} \rightarrow{ }^{1} \mathrm{~T}_{2 \mathrm{~g}}\end{array}$ & - & - & - & - & - \\
\hline
\end{tabular}


first excited doublet levels in order of increasing energy are ${ }^{2} \mathrm{~A}_{2 \mathrm{~g}}$ and ${ }^{2} \mathrm{~T}_{1 \mathrm{~g}}$, which are known to arise from the $\mathrm{t}_{2 \mathrm{~g}}{ }^{4} \mathrm{e}_{1 \mathrm{~g}}$ configuration. ${ }^{28}$ The Ru(III) complex shows three electronic transitions at $13568 \mathrm{~cm}^{-1}, 19048 \mathrm{~cm}^{-1}$ and $22124 \mathrm{~cm}^{-1}$, which may be assigned to ${ }^{2} \mathrm{~T}_{2 \mathrm{~g}} \rightarrow{ }^{4} \mathrm{~T}_{1 \mathrm{~g}}(\nu 1),{ }^{2} \mathrm{~T}_{2 \mathrm{~g}} \rightarrow{ }^{4} \mathrm{~T}_{2 \mathrm{~g}}(\nu 2)$, and ${ }^{2} \mathrm{~T}_{2 \mathrm{~g}} \rightarrow{ }^{2} \mathrm{~A}_{2 \mathrm{~g}}$ $(\nu 3)$ in increasing order of energy. The interelectronic repulsion parameters ( $B$, and $C$ ) and ligand field parameters (10Dq) parameters were calculated using the following equations: ${ }^{29}$

$$
\begin{gathered}
{ }^{2} \mathrm{~T}_{2 \mathrm{~g}} \rightarrow{ }^{4} \mathrm{~T}_{1 \mathrm{~g}}(\nu 1)=10 \mathrm{Dq}-5 B-4 C, \\
{ }^{2} \mathrm{~T}_{2 \mathrm{~g}} \rightarrow{ }^{4} \mathrm{~T}_{2 \mathrm{~g}}(\nu 2)=10 \mathrm{Dq}+3 B-4 C, \\
{ }^{2} \mathrm{~T}_{2 \mathrm{~g}} \rightarrow{ }^{2} \mathrm{~A}_{2 \mathrm{~g}}, \\
{ }^{2} \mathrm{~T}_{1 \mathrm{~g}}(\nu 3)=10 \mathrm{Dq}-2 B-C
\end{gathered}
$$

The values of the ligand field parameters are comparable to those of different ruthenium(III) complexes reported in the literature. ${ }^{30}$ The Racah interelectronic repulsion parameter $(B)$ observed for this complex is less than that for a $\mathrm{Ru}(\mathrm{III})$ ion $\left(B^{\prime}=\right.$ $\left.630 \mathrm{~cm}^{-1}\right) .{ }^{30}$ The $10 \mathrm{Dq}$ value is high and the nephelauxetic parameter $\left(\beta=\frac{B}{B^{\prime}}\right)$ is $\leq 1.0$. The decrease in $\beta$ value is also associated with a reduction in the effective positive charge of the metal ion and with an increasing tendency to reduction to the lower oxidation state. ${ }^{31}$ These results suggest the presence of strong covalent bonding between the Pip- $\mathrm{H}$ donor and $\mathrm{Ru}^{3+}$ ions. $^{30}$ The magnetic susceptibility of $\left[\mathrm{Ru}(\mathrm{Pip}-\mathrm{H})_{3}(\mathrm{Cl})_{3}\right] \cdot 6 \mathrm{H}_{2} \mathrm{O}$ complex (1) was measured using a Gouy magnetic balance at room temperature. The ruthenium(III) complex being $\mathrm{d}^{5}$ (low spin), $S=1 / 2$ has a paramagnetic character. The magnetic

\begin{tabular}{|c|c|}
\hline Pip-H & $\begin{array}{l}1.36\left(3 \mathrm{H}_{8 \mathrm{~b}}:-\underline{\mathrm{CH}}_{3} \mathrm{CH}_{2}\right), 3.14-3.25\left(4 \mathrm{H}_{2 \mathrm{a}, 2 \mathrm{a}^{\prime}} \text { : piperazinyl group }\right), 3.86\left(4 \mathrm{H}_{2 \mathrm{~b}, 2 \mathrm{~b}}: \text { piperazinyl group }\right), \\
4.39\left(2 \mathrm{H}_{8 \mathrm{a}}:-\mathrm{CH}_{3} \underline{\mathrm{CH}}_{2}\right), 8.90\left(2 \mathrm{H}_{4,7}: \text { pyrimidine and quinolone groups }\right) ; 9.19\left(1 \mathrm{H}_{11}:-\mathrm{NH} \text { piperazinyl group }\right)\end{array}$ \\
\hline
\end{tabular}

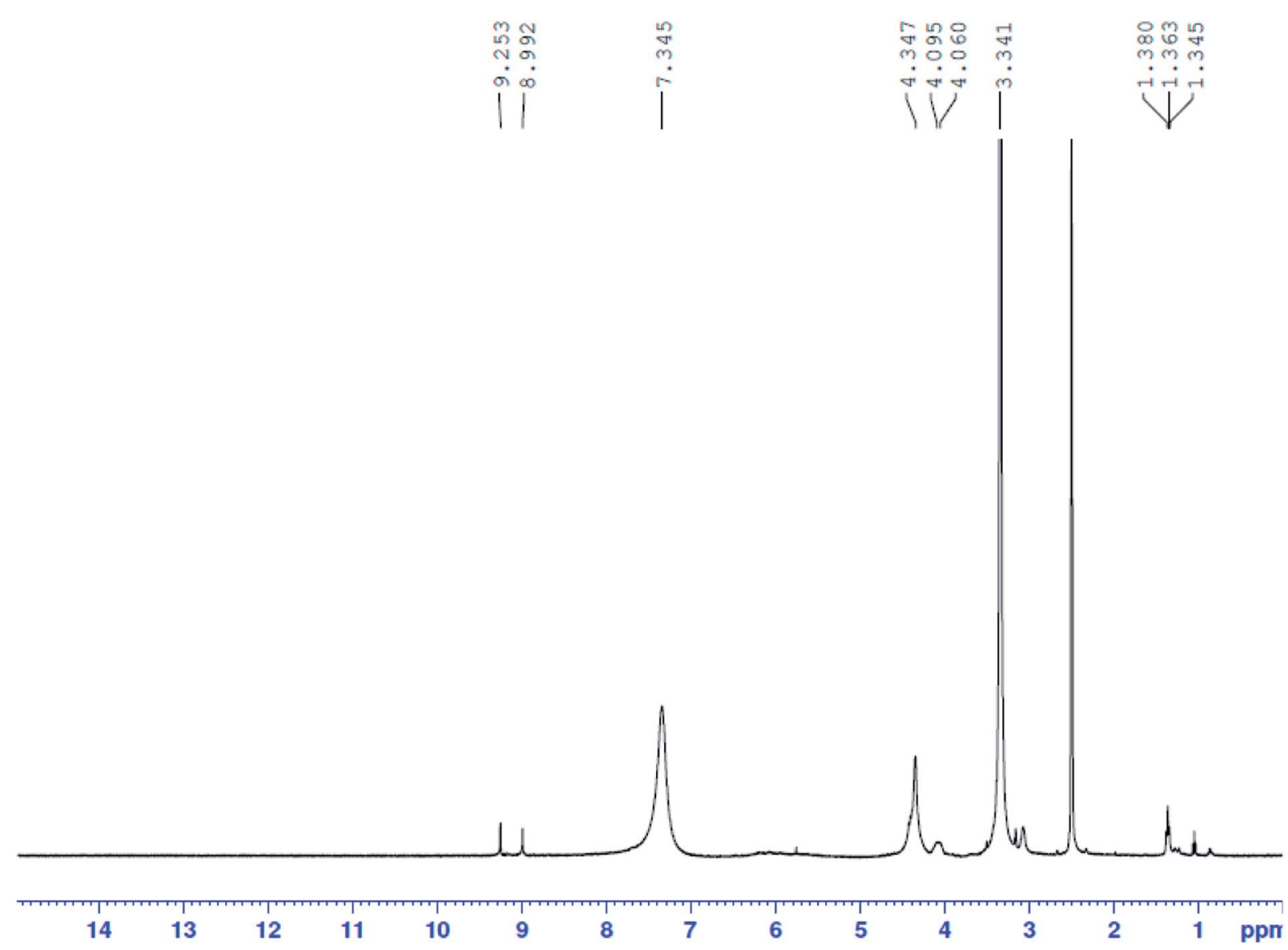

Fig. $5{ }^{1} \mathrm{H}-\mathrm{NMR}$ spectrum of Pt(Iv) complex 2.

Table $5{ }^{1} \mathrm{H}-\mathrm{NMR}$ data of Pip-H and its Pt(IV) complex 2 
moment of the ruthenium(III) Pip-H complex is 1.90 B.M., which confirms the exhibition of a single unpaired electron in a low-spin $4 \mathrm{~d}^{5}$ configuration for a $\mathrm{Ru}^{3+}$ ion in an octahedral environment. ${ }^{32}$ This value is lower than the predicted value of 2.10 B.M. This lowering may be due to the presence of ligand fields of lower symmetry, or extensive electron delocalization in the species. ${ }^{33}$ Therefore, the magnetic moment value gives an impression that the ruthenium(III) complex has been found in the $(+3)$ oxidation state.

The electronic spectrum of $\left[\mathrm{pt}\left(\mathrm{Pip}-\mathrm{NH}_{4}\right)_{2}(\mathrm{Cl})_{4}\right]$ complex (2) shows that charge transfer transitions may interfere and prevent the observation of all the expected bands. ${ }^{34}$ The distinct bands at 326 and $354 \mathrm{~nm}$ are assignable to a combination of metal ligand charge transfer $\left(\mathrm{M} \rightarrow \mathrm{L}_{\mathrm{CT}}\right)$ and $\mathrm{d}-\mathrm{d}$ transition band. The other weak band at $389 \mathrm{~nm}$ is attributed to a combination of $\mathrm{N} \rightarrow \mathrm{Pt}$ (Iv) metal charge transfer $\left(\mathrm{L} \pi \rightarrow \mathrm{M}_{\mathrm{CT}}\right)$ and $\mathrm{d}-$ $\mathrm{d}$ transition bands. The Pt(Iv) complex 2 is found to be diamagnetic in character, so the platinum(Iv) complex must have octahedral geometry. The $\mathrm{Pt}(\mathrm{Iv})$ is a $\mathrm{d}^{6}$ system and four bands are expected due to ${ }^{1} \mathrm{~A}_{1 \mathrm{~g}} \rightarrow{ }^{3} \mathrm{~T}_{1 \mathrm{~g}},{ }^{1} \mathrm{~A}_{1 \mathrm{~g}} \rightarrow{ }^{3} \mathrm{~T}_{2 \mathrm{~g}},{ }^{1} \mathrm{~A}_{1 \mathrm{~g}} \rightarrow{ }^{1} \mathrm{~T}_{1 \mathrm{~g}}$ and ${ }^{1} \mathrm{~A}_{1 \mathrm{~g}} \rightarrow{ }^{1} \mathrm{~T}_{2 \mathrm{~g}}$ transitions. The shift to lower frequency after complexation is due to the binding between the Pt(Iv) ion and the nitrogen atom of the piperazyl ring.

The iridium(III) complex 3 is diamagnetic in character. The $\mathrm{UV}$-vis spectrum of $\left[\operatorname{Ir}(\mathrm{Pip}-\mathrm{H})_{3}(\mathrm{Cl})_{3}\right] \cdot 6 \mathrm{H}_{2} \mathrm{O}$ shows bands in the range of $26525-30675 \mathrm{~cm}^{-1}$ and $34246-34602 \mathrm{~cm}^{-1}$. These two regions can be deduced from the ground state ${ }^{1} \mathrm{~A}_{1 \mathrm{~g}}$ and exist in the expected ranges ${ }^{35}$ for two spin-allowed transitions ${ }^{1} \mathrm{~A}_{1 \mathrm{~g}} \rightarrow$ ${ }^{1} \mathrm{~T}_{1 \mathrm{~g}}(\nu 1)$ and ${ }^{1} \mathrm{~A}_{1 \mathrm{~g}} \rightarrow{ }^{1} \mathrm{~T}_{2 \mathrm{~g}}(\nu 2)$. The ratio $\nu 2 / \nu 1$ in the $\operatorname{Ir}(\mathrm{III})$ complex 3 is 1.12 , which is agreement with the octahedral geometry for iridium(III) complexes in the literature. ${ }^{36}$ The ${ }^{1} \mathrm{~A}_{1 \mathrm{~g}}$ $\rightarrow{ }^{1} \mathrm{~T}_{1 \mathrm{~g}}(\nu 1)$ and ${ }^{1} \mathrm{~A}_{1 \mathrm{~g}} \rightarrow{ }^{1} \mathrm{~T}_{2 \mathrm{~g}}(\nu 2)$ transitions have been used to calculate the ligand field parameters $10 \mathrm{Dq}$ and nephelauxetic (B) based on the following equations: ${ }^{31}$

$$
\begin{aligned}
& \nu 1=10 \mathrm{Dq}-4 B+\frac{86(B)^{2}}{10 \mathrm{Dq}} \\
& \nu 2=10 \mathrm{Dq}+12 B+\frac{2(B)^{2}}{10 \mathrm{Dq}}
\end{aligned}
$$

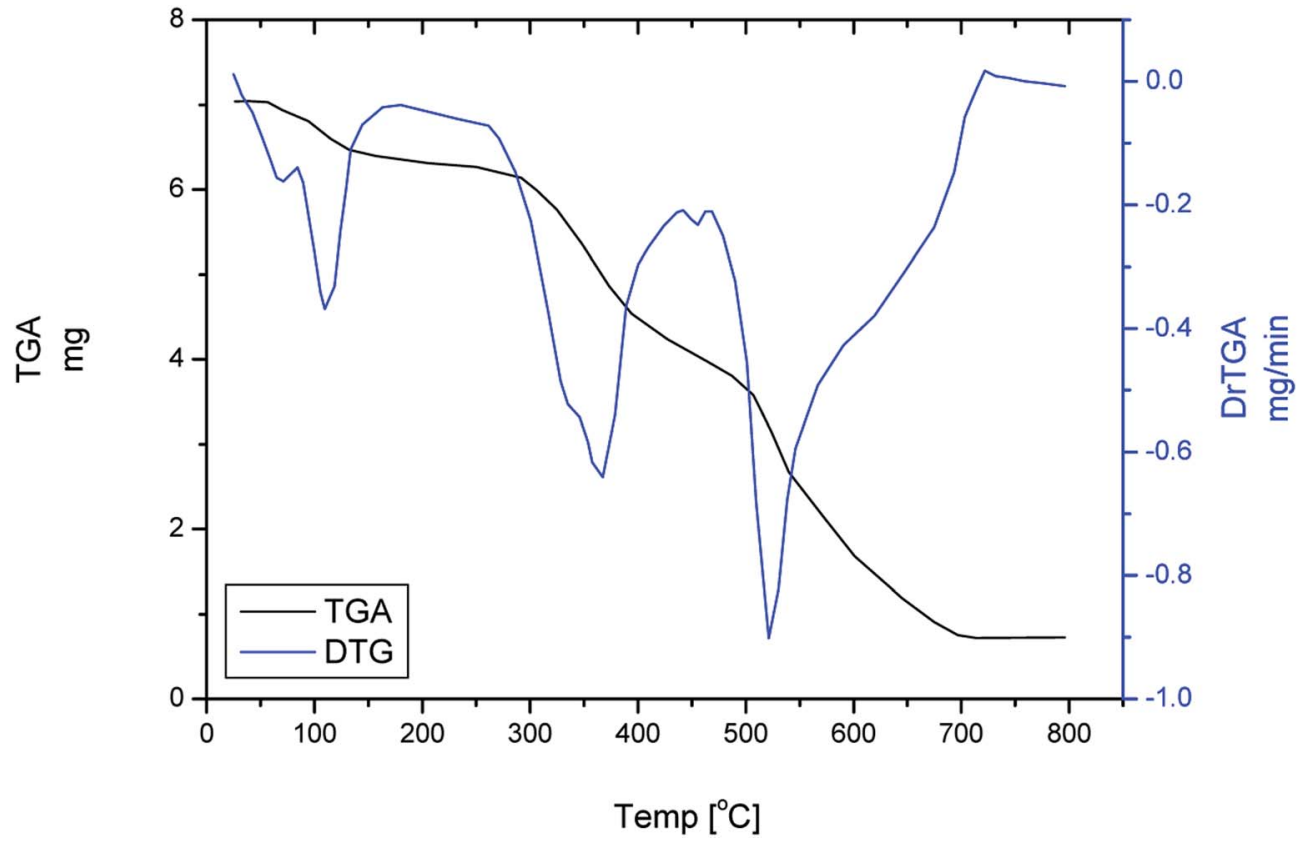

Fig. 6 TGA and DTG of $\left[\mathrm{Ru}(\mathrm{Pip}-\mathrm{H})_{3}(\mathrm{Cl})_{3}\right] \cdot 6 \mathrm{H}_{2} \mathrm{O}$ complex 1 .

\begin{tabular}{|c|c|c|c|c|c|c|c|c|}
\hline Complex & Stage & Method & $E\left(\mathrm{~J} \mathrm{~mol}^{-1}\right)$ & $A\left(\mathrm{~s}^{-1}\right)$ & $\Delta S\left(\mathrm{~J} \mathrm{~mol}^{-1} \mathrm{~K}^{-1}\right)$ & $\Delta H\left(\mathrm{~J} \mathrm{~mol}^{-1}\right)$ & $\Delta G\left(\mathrm{~J} \mathrm{~mol}^{-1}\right)$ & $r$ \\
\hline & & $\mathrm{HM}$ & $8.32 \times 10^{4}$ & $4.95 \times 10^{4}$ & $-1.61 \times 10^{2}$ & $7.79 \times 10^{4}$ & $1.80 \times 10^{5}$ & 0.9677 \\
\hline \multirow[t]{2}{*}{2} & 2nd & $\mathrm{CR}$ & $1.56 \times 10^{5}$ & $3.74 \times 10^{10}$ & $-4.88 \times 10^{1}$ & $1.51 \times 10^{5}$ & $1.82 \times 10^{5}$ & 0.9394 \\
\hline & & HM & $1.56 \times 10^{5}$ & $6.81 \times 10^{10}$ & $-4.39 \times 10^{1}$ & $1.51 \times 10^{5}$ & $1.79 \times 10^{5}$ & 0.9314 \\
\hline
\end{tabular}

Table 6 Thermodynamic parameters of the thermal decomposition of Ru(III), Pt(IV) and Ir(III) Pip-H complexes 1-3 
The outcome data of $\nu 2 / \nu 1,10 \mathrm{Dq}, B, C$ and $\beta$ parameters are in agreement with other iridium(III) complexes in previous studies. ${ }^{35,36}$ The B value is about $34 \%$ of the free iridium ion $\left(660 \mathrm{~cm}^{-1}\right)$ in the $\operatorname{Ir}(\mathrm{III})$ complexes, which refers to the overlap with significant covalency in the metal ligand $\sigma$-bond.

\section{4 ${ }^{1}$ H-NMR spectra}

${ }^{1} \mathrm{H}-\mathrm{NMR}$ spectra of Pip-H and $\left[\mathrm{pt}\left(\mathrm{Pip}-\mathrm{NH}_{4}\right)_{2}(\mathrm{Cl})_{4}\right]$ complex (2) have been recorded in $\mathrm{d}_{6}$-DMSO. The assignment of each signal has been achieved by comparing the ${ }^{1} \mathrm{H}-\mathrm{NMR}$ spectrum of the $\mathrm{Pt}$ (Iv) complex (Fig. 5) to that of the Pip-H free drug ligand and these spectra have been reported in the literature. ${ }^{37}$ The assignable results are shown in Table 5. The proton-NMR spectrum of the platinum(Iv) complex showed a set of signals which were almost identical to those of Pip-H, while shifts occurred particularly at the piperazinyl protons $\left(\left(3.341\left(4 \mathrm{H}_{2 \mathrm{a}, 2 \mathrm{a}^{\prime}}\right.\right.\right.$ : piperazinyl group) and 4.060, $4.095\left(4 \mathrm{H}_{2 \mathrm{~b}, 2 \mathrm{~b}^{\prime}}\right.$ : piperazinyl group $\left.)\right)$ and the singlet proton of the $-\mathrm{NH}$ piperazinyl group (9.253(1 $\mathrm{H}_{11}$ : $-\mathrm{NH}$ piperazinyl group)). The singlet peak at $\delta=$ $7.345 \mathrm{ppm}$ was assigned to eight protons of two $-\mathrm{NH}_{4}$ groups which existed instead of the deprotonated carboxylic group. The spectrum showed a singlet peak at $\delta=4.347 \mathrm{ppm}$ for $-\mathrm{CH}_{2}$ protons and a singlet at $\delta=8.992 \mathrm{ppm}$ for the two protons of the pyrimidine and quinolone moieties at positions $\mathrm{H} 4$ and $\mathrm{H} 7$ (Table 5). No broad weak band for the acidic proton at $\delta=11.00$ ppm can be seen in the spectrum of complex 2, indicating that this moiety is deprotonated by the $-\mathrm{NH}_{4}$ basic ion, so Pip-H acts as a uni-dentate deprotonated ligand bound to the target metal ion through the piperazinyl nitrogen and completed coordination sphere by chlorine atoms. ${ }^{38}$

\subsection{Thermal analyses and thermodynamic parameters}

Thermogravimetric (TG) and differential thermogravimetric (DTG) analyses were carried out to identify the formulas of Ru(III), Pt(Iv) and Ir(III) Pip-H complexes 1-3 reported in this study. TGA and DTG thermograms are performed under $\mathrm{N}_{2}$ flow, as shown in Fig. 6a-c. Table 6 includes the maximum temperature values, $\mathrm{DTG}_{\max }{ }^{\circ} \mathrm{C}^{-1}$, and the mass losses of the thermal decomposition steps for each synthetic complex. The thermal data led us to find the number of crystallized water molecules outside the coordination sphere for Pip-H complexes 1-3.

The thermal decomposition of $\left[\mathrm{Ru}(\mathrm{Pip}-\mathrm{H})_{3}(\mathrm{Cl})_{3}\right] \cdot 6 \mathrm{H}_{2} \mathrm{O}$ complex (1) proceeds with approximately three main degradation steps (Fig. 6). The first stage occurs at a maximum temperature of $103{ }^{\circ} \mathrm{C}$ with weight loss of $9.863 \%$ (theoretical $8.810 \%$ ) due to dehydrated $6 \mathrm{H}_{2} \mathrm{O}$ crystallization water molecules. Therefore, it could be associated with changes in the lattice structures. While the second and third stages occur at two different maximum temperatures of 345 and $554{ }^{\circ} \mathrm{C}$. The weight loss associated with these stages is $80.584 \%$, which is very close to the theoretical value of $81.637 \%$ corresponding to the loss of three Pip-H molecules. The final thermal product obtained at $800{ }^{\circ} \mathrm{C}$ is $\mathrm{RuO}$ (found 9.553\%; theoretical 9.553\%).

Table 7 The XRD collected data of crystallite sizes $(D)$, dislocation density $(\delta), 2 \theta$, intensities, and $d$-spacing

\begin{tabular}{llllll}
\hline Complex & $D(\mathrm{~nm})$ & $\delta\left(10^{12} \operatorname{lin~}^{-2}\right)$ & 2 theta & Intensity & $d$-Spacing \\
\hline Complex 1 & 28 & 0.001 & 21 & 100 & 4.2088 \\
Complex 2 & 22 & 0.002 & 24 & 100 & 3.6395 \\
Complex 3 & 14 & 0.005 & 24 & 100 & 3.6395
\end{tabular}

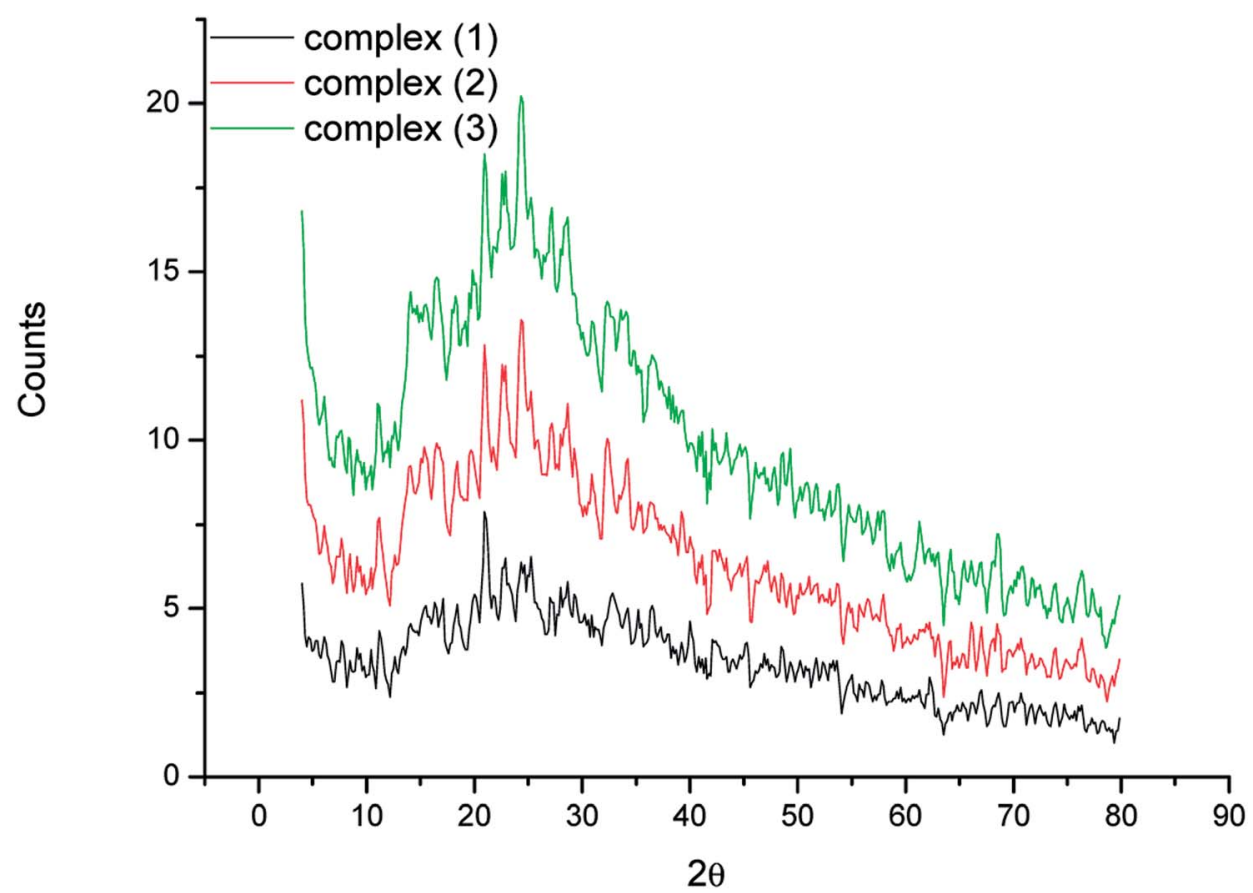

Fig. 7 X-ray powder diffraction patterns of $\left[\mathrm{M}(\mathrm{L})_{n}(\mathrm{Cl})_{x}\right] \cdot y \mathrm{H}_{2} \mathrm{O}\left((1) \mathrm{M}=\mathrm{Ru}^{3+}, \mathrm{L}: \mathrm{Pip}-\mathrm{H}, n=3, x=3, y=6 ;(2) \mathrm{M}=\mathrm{Pt}^{4+}, \mathrm{L}: \mathrm{Pip}^{-\mathrm{NH}}{ }_{4}, n=2, x=4, y=\right.$ 0 and (3) $\left.\mathrm{M}=1 \mathrm{r}^{3+}, \mathrm{L}: \mathrm{Pip}-\mathrm{H}, n=3, x=3, y=6\right)$ complexes $1-3$. 
The thermal degradation of $\left[\mathrm{pt}\left(\mathrm{Pip}-\mathrm{NH}_{4}\right)_{2}(\mathrm{Cl})_{4}\right]$ complex (2) takes place with three degradation stages. This complex is anhydrous, so the first stage of decomposition occurs at a high maximum temperature of $258{ }^{\circ} \mathrm{C}$. Therefore, the complex starts to decompose at the first $\mathrm{DTG}_{\max }$ and continuously decomposes through the second and third stages, with a total weight loss of $80.475 \%$, corresponding to the loss of two Pip- $\mathrm{NH}_{4}$ molecules. Theoretically, the loss of these molecules corresponds to a weight loss of $80.045 \%$. The weight found for the residue ( $\mathrm{Pt}$ metal) after final decomposition is $19.525 \%$ (theoretical, $19.955 \%$ ) giving an actual total weight loss in agreement with our calculated total weight loss value of $80.475 \%$.

The thermal decomposition of $\left[\mathrm{Ru}(\mathrm{Pip}-\mathrm{H})_{3}(\mathrm{Cl})_{3}\right] \cdot 6 \mathrm{H}_{2} \mathrm{O}$ complex (3) proceeds with three main degradation steps. The first stage of the decomposition occurs at a maximum temperature of $67^{\circ} \mathrm{C}$ and is accompanied by a weight loss of $8.295 \%$ corresponding to the loss of the six uncoordinated water molecules. Theoretically, the loss of these molecules corresponds to a weight loss of $8.203 \%$, which agrees with the experimental result. The second and third decomposition stages occur at maximum temperatures of 317 and $587{ }^{\circ} \mathrm{C}$, respectively. The weight loss at these steps is $73.224 \%$ associated with the loss of three Pip- $\mathrm{H}$ molecules. The theoretical weight loss value is $74.767 \%$. The weight found for the residue after decomposition is $18.481 \%$, giving an actual total weight loss in agreement with our calculated total weight loss value of $17.030 \%$. The final thermal decomposition product is $\mathrm{IrO}_{2}$.

Three different methods are used for the evaluation of the kinetic parameters: the Freeman and Carroll (FC) differential method, ${ }^{39}$ the Horowitz and Metzger (HM) approximation method $^{40}$ and the Coats and Redfern (CR) integral method ${ }^{41}$. The kinetic parameters were evaluated by using two of these methods: the Horowitz and Metzger (HM) approximation method $^{40}$ and the Coats and Redfern (CR) integral method, ${ }^{41}$ and the data are listed in Table 6 . The satisfactory values of correlation coefficients $(\sim 1)$ in all cases indicate good agreement with the experimental data and the values of the kinetic parameters are reasonable and in good agreement.

Table 6 can be used to make some points:

(i) The higher values of activation energies $\mathrm{Pt}(\mathrm{Iv})$ $\left(156 \mathrm{~kJ} \mathrm{~mol}^{-1}\right)>\mathrm{Ru}$ (III) $\left(78.35 \mathrm{~kJ} \mathrm{~mol}^{-1}\right)>\operatorname{Ir}\left(\right.$ III) $\left(38.20 \mathrm{~kJ} \mathrm{~mol}^{-1}\right)$ lead to the thermal stability of the Pip-H complexes.
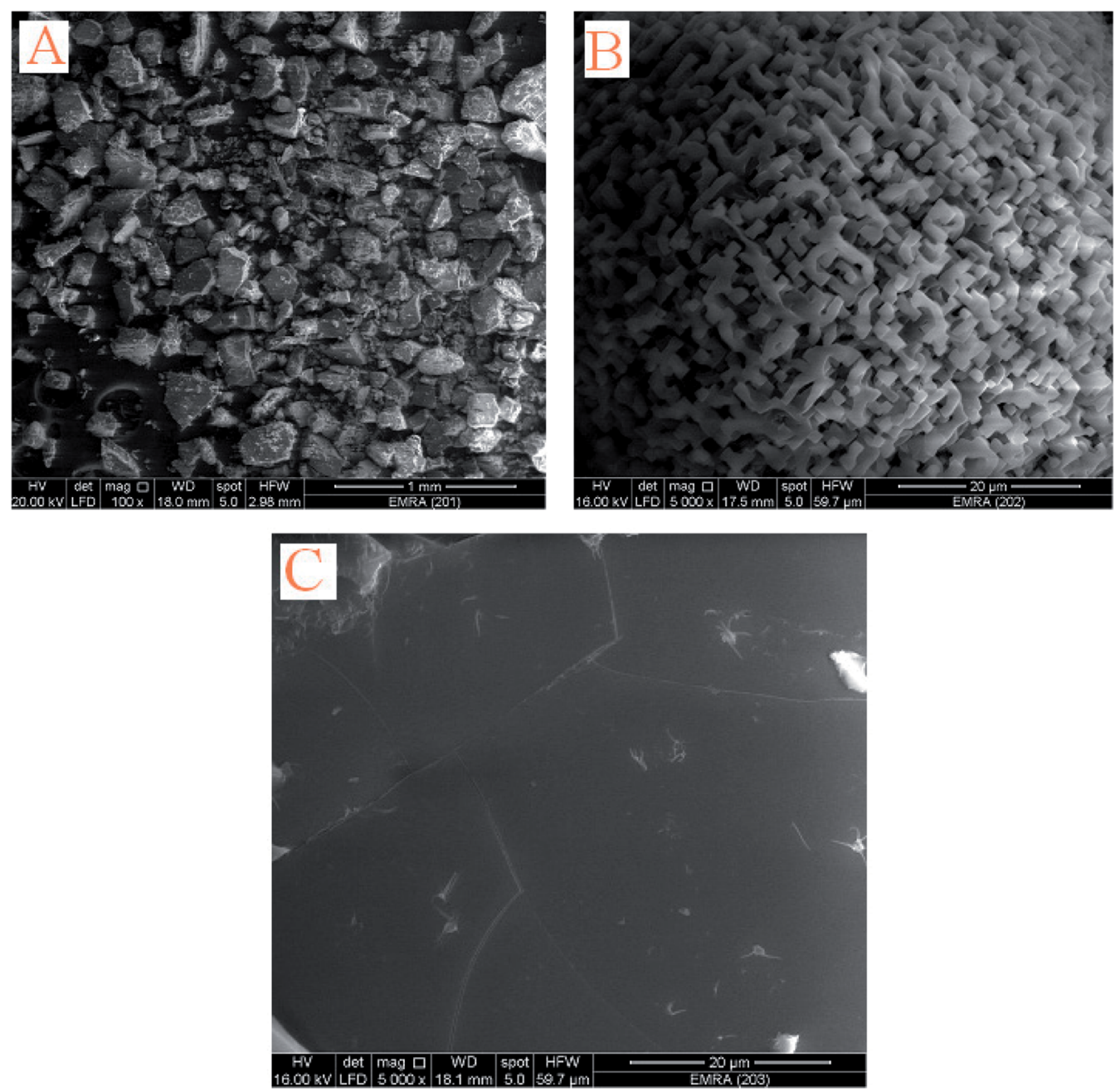

Fig. $8 \mathrm{SEM}$ images of $\left[\mathrm{M}(\mathrm{L})_{n}(\mathrm{Cl})_{x}\right] \cdot y \mathrm{H}_{2} \mathrm{O}\left((\mathrm{A}) \mathrm{M}=\mathrm{Ru}^{3+}, \mathrm{L}: \mathrm{Pip}-\mathrm{H}, n=3, x=3, y=6\right.$; (B) $\mathrm{M}=\mathrm{Pt}^{4+}, \mathrm{L}: \mathrm{Pip}-\mathrm{NH}_{4}, n=2, x=4, y=0$ and $(\mathrm{C}) \mathrm{M}=\mathrm{Ir}{ }^{3+}, \mathrm{L}$ : Pip-H, $n=3, x=3, y=6$ ) complexes 1-3. 
(ii) The thermodynamic data resulting from the two methods are in harmony with each other.

(iii) The correlation coefficients $(r)$ of the Arrhenius plots of the thermal decomposition steps were found to lie in the range 0.98-0.93, showing a good fit with the linear function.

(iv) It is clear that the process of thermal decomposition of the complexes is non-spontaneous $\left(\Delta S^{*}=\right.$ negative value); i.e., the complexes are thermally stable.

\subsection{X-ray powder diffractions}

The X-ray solid powder diffractions of $\left[\mathrm{M}(\mathrm{L})_{n}(\mathrm{Cl})_{x}\right] \cdot y \mathrm{H}_{2} \mathrm{O}((\mathbf{1}) \mathrm{M}$ $=\mathrm{Ru}^{3+}$, L: Pip-H, $n=3, x=3, y=6$; (2) $\mathrm{M}=\mathrm{Pt}^{4+}$, L: Pip- $\mathrm{NH}_{4}, n$ $=2, x=4, y=0$ and (3) $\mathrm{M}=\mathrm{Ir}^{3+}$, L: Pip-H, $n=3, x=3, y=6$ ) complexes 1-3 are shown in Fig. 7. These diffraction patterns are semi-crystalline in nature. The particle size $(D)$ of $\mathrm{Pip}-\mathrm{H}$ complexes 1-3 was estimated from the major diffraction patterns of the respective complex using the Debye-Scherrer formula (eqn (1)): ${ }^{42}$

$$
D=\frac{K \lambda}{\beta \cos \theta}
$$

where $\lambda$ is the wavelength of the X-ray $(1.5418 \AA$ ) for $\mathrm{Cu} \mathrm{K} \alpha$ radiation, $K$ is a constant taken to be $0.94, \beta$ is the full width at half maximum (FWHM) of the prominent intensity peak $(100 \%$ relative intensity peak), and $\theta$ is a peak position. The grain sizes using the Debye-Scherrer formula were found to be 28, 22 and $14 \mathrm{~nm}$ for Ru(III), Pt(Iv) and Ir(III) complexes, respectively. The lower grain size can be discussed according to the increase in Pip-H chelates around the metal ions (ratio $1: 3$ or $1: 2$ ). ${ }^{43}$ The collected data of XRD such as $2 \theta$, intensities and d-spacing are listed in Table 7 . The dislocation density $(\delta)$ was evaluated from eqn (2) ${ }^{\mathbf{4 4}}$ and is listed in Table 7; it indicates the formation of high-quality complexes.

$$
\delta=\frac{1}{D^{2}}
$$

The XRD of the Ru(III) complex has three significant peaks at $36.47,45.35$, and $48.41^{\circ}$ due to the presence of the (002), (100), and (101) planes of ruthenium metal. ${ }^{45}$ The XRD patterns due to metallic platinum (JCPDS PDF card no. 04-0802) ${ }^{\mathbf{4 6}}$ are present at $41.07,51.16$, and $66.00^{\circ}$ for the (111), (200), and (220) planes,
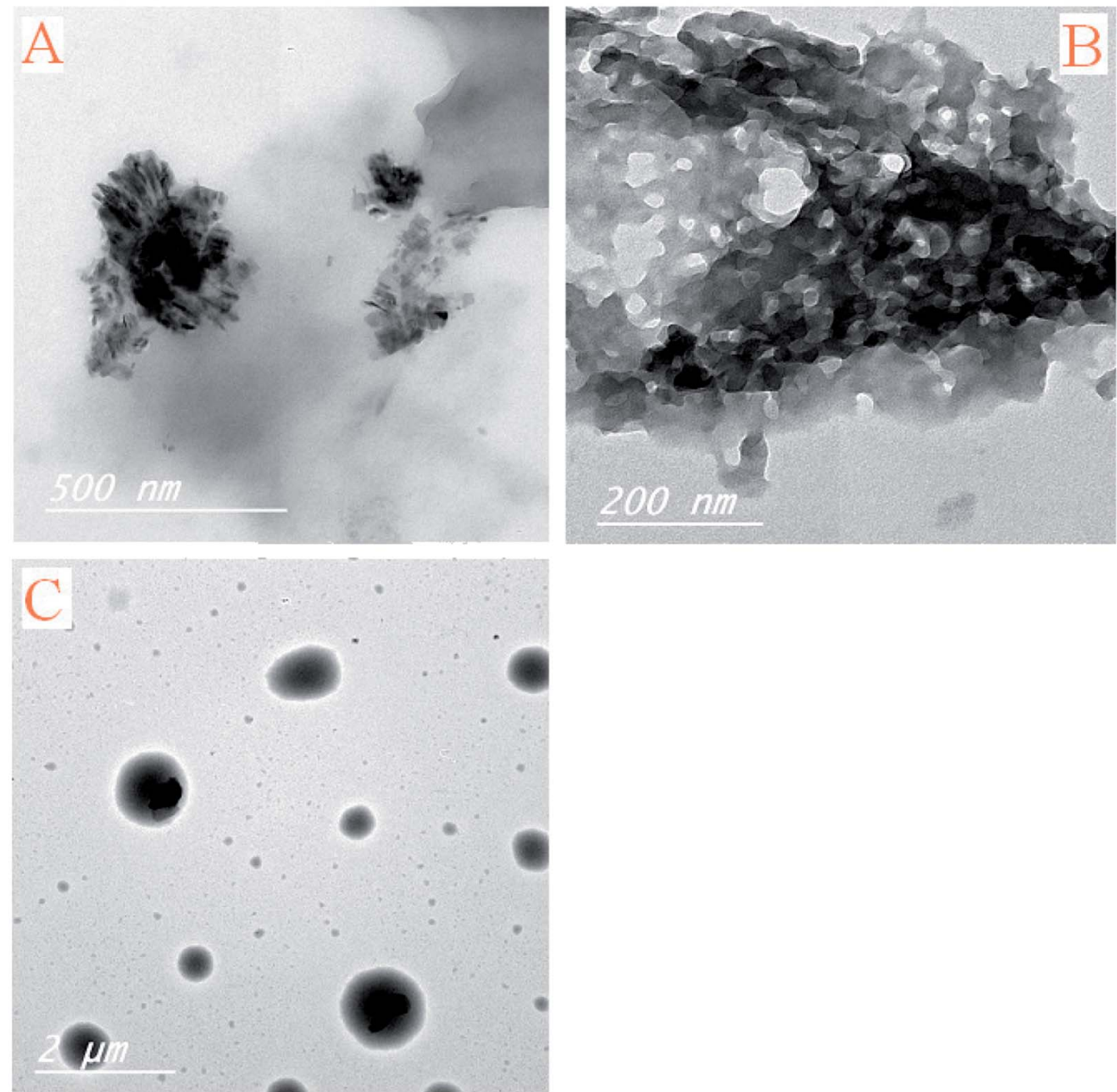

Fig. 9 TEM images of $\left[\mathrm{M}(\mathrm{L})_{n}(\mathrm{Cl})_{x}\right] \cdot y \mathrm{H}_{2} \mathrm{O}\left((\mathrm{A}) \mathrm{M}=\mathrm{Ru}^{3+}, \mathrm{L}: \mathrm{Pip}-\mathrm{H}, n=3, x=3, y=6\right.$; (B) $\mathrm{M}=\mathrm{Pt}^{4+}, \mathrm{L}: \mathrm{Pip}-\mathrm{NH}_{4}, n=2, x=4, y=0$ and $(\mathrm{C}) \mathrm{M}=\mathrm{Ir}{ }^{3+}, \mathrm{L}$ : Pip-H, $n=3, x=3, y=6)$ complexes $1-3$. 
respectively. XRD patterns of the synthesized iridium metal in situ of the Ir(III) complex agreed well with standard card JCPDS no. 06-0598 for bulk iridium at $2 \theta=41.75,49.09$, and $68.57^{\circ}$. The considerably broadened contours of the peaks resulted from the ultrasmall grain sizes of iridium metal. ${ }^{47}$

\subsection{SEM and TEM morphology}

The scanning electron microscope images are used here to investigate the surface morphology and particle size of the Pip$\mathrm{H}$ complexes 1-3, revealing a crystalline, regular, and glassy structure. Layers in the micrograph reveal that the system contains atoms in a well-defined pattern; thus the reactants have reacted completely to form a clear homogenous compound. In general, the SEM photograph shows single phase formation with well-defined grain-like shape and particle size in the range of $1 \mathrm{~mm}$ to $20 \mu \mathrm{m}$. The SEM images of the Pip-H complexes 1-3 are depicted in Fig. 8a-c.

TEM photos of Pip-H complexes 1-3 (Fig. 9a-c) confirm the presence of spherical or semispherical NPs, which appear as dark spots.

\subsection{Redox behavior of $\left[\operatorname{Ir}(\mathrm{Pip}-\mathrm{H})_{3}(\mathrm{Cl})_{3}\right] \cdot 6 \mathrm{H}_{2} \mathrm{O}$}

Cyclic voltammograms (CVs) of the complex $\left[\operatorname{Ir}(\mathrm{Pip}-\mathrm{H})_{3}(\mathrm{Cl})_{3}\right]$. $6 \mathrm{H}_{2} \mathrm{O}$ in $(\mathrm{Bu})_{4} \mathrm{~N}^{+} \cdot \mathrm{BF}_{4}{ }^{-}-\mathrm{DMSO}$ solution at $100 \mathrm{mV} \mathrm{s}^{-1}$ vs. $\mathrm{Ag} /$ $\mathrm{AgCl}$ electrode are shown in Fig. 10. One well-defined anodic peak at $1.25 \mathrm{~V}$ is assigned to the $\mathrm{Ir}^{3+} / \mathrm{Ir}^{4+}$ electrode couple. In the
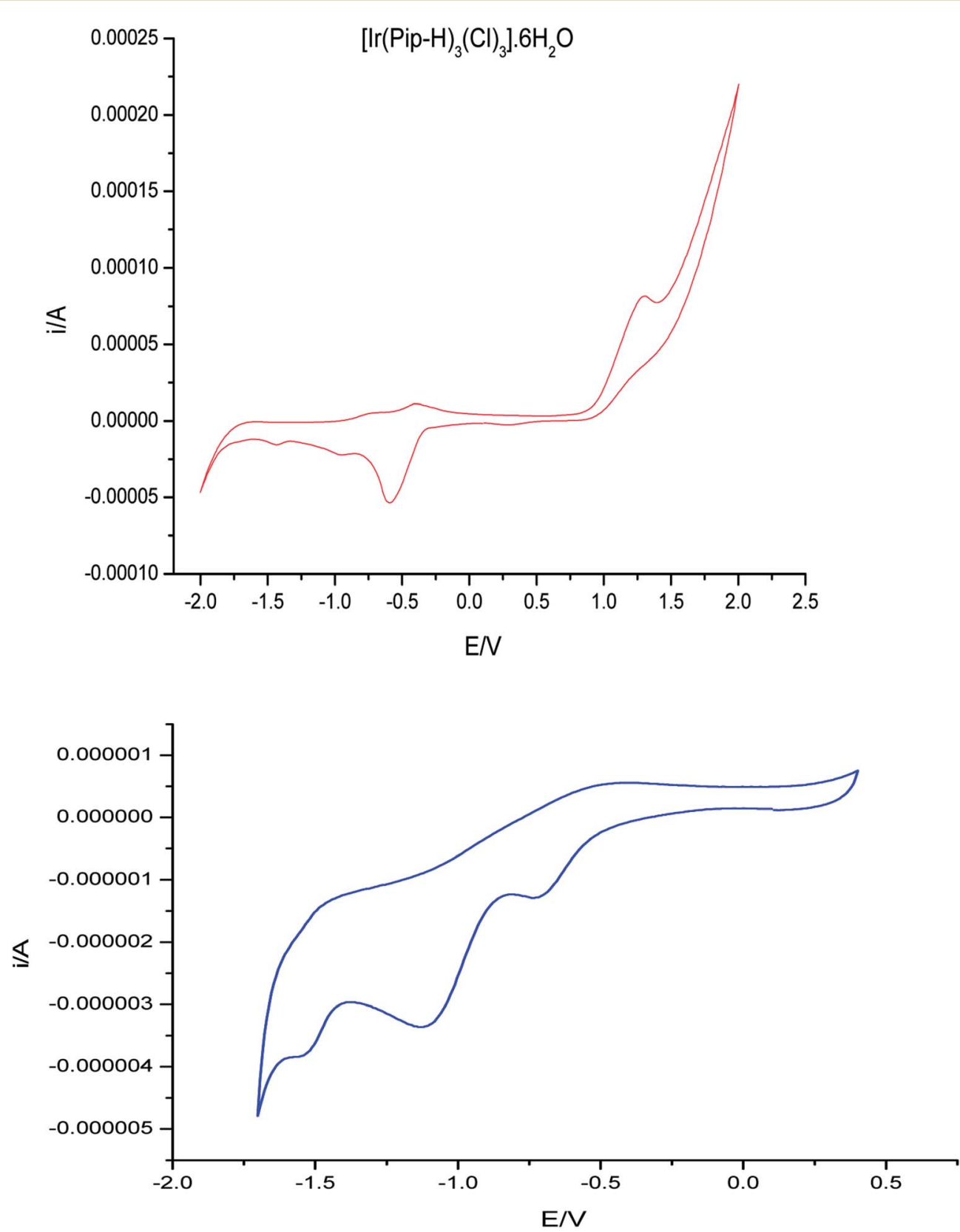

Fig. $10 \mathrm{CV}$ of $\left(\operatorname{Ir}(\mathrm{Pip}-\mathrm{H})_{3}(\mathrm{Cl}) 3\right] \cdot 6 \mathrm{H} 2 \mathrm{O}$ in $(\mathrm{Bu})_{4} \mathrm{~N}^{+} \cdot \mathrm{BF}_{4}{ }^{-}-\mathrm{DMSO}$ solution at $100 \mathrm{mV} \mathrm{s}{ }^{-1} \mathrm{vs}$. Ag/AgCl, voltage. 
reverse scan, three well-defined cathodic peaks at $-0.6,-1.1$ and $-1.5 \mathrm{~V}$ were noticed and were safely assigned to the couples $\mathrm{Ir}^{4+} / \mathrm{Ir}^{3+}, \mathrm{Ir}^{3+} / \mathrm{Ir}^{2+}$ and the ligand centre. ${ }^{48}$ The potential-potential difference $\left(\Delta E_{\mathrm{p}}=E_{\mathrm{p}, \mathrm{a}}-E_{\mathrm{p}, \mathrm{c}}\right)$ was $<90 \mathrm{mV}$, revealing the quasi-reversible nature of the reduction process. The irreversible nature of the couple $\mathrm{Ir}^{4+} / \mathrm{Ir}^{3+}$ was also confirmed from the observed increase in $\Delta E_{\mathrm{p}}$ on increasing the scan rate. Thus, the couple $\mathrm{Rh}^{4+} / \mathrm{Rh}^{3+}$ is most likely to be irreversible metal-based reduction. ${ }^{48,49}$

The plot of $i_{\mathrm{p}, \mathrm{c}}$ vs. $\nu^{1 / 2}$ was linear $\left(R^{2}=0.986\right)$ (Fig. 11) reflecting the diffusion-controlled feature of the electrochemical process. ${ }^{48,49}$

The variation in the current function $\left(i_{\mathrm{p}, \mathrm{c}} / \nu^{1 / 2}\right)$ with the scan rate (50-2000 $\mathrm{mV} \mathrm{s}^{-1}$ ) was also studied. The plot of the current function $\left(i_{\mathrm{p}, \mathrm{c}} / \nu^{1 / 2}\right) v s$. the scan rate $(\nu)$ increased linearly at a low sweep rate (Fig. 12). Thus, the reduction process of the complex favors the EE-type mechanism. ${ }^{50}$ The product of this reduction step undergoes a very rapid follow-up chemical reaction and the redox processes are of the EE type. ${ }^{\mathbf{4 9 , 5 0}}$ The observed behavior may possibly be explained by considering that the protonation reaction is very fast or virtually complete. The irreversibility and most often quasi-reversibility is attributed to the adsorption onto the electrode surface.

\subsection{Biological studies}

3.9.1 Antibacterial assessments. The antibacterial efficiency of pipemidic acid complexes (Pip-H) with $\mathrm{Ru}^{3+}, \mathrm{Pt}^{4+}$ and $\mathrm{Ir}^{3+}$ was assessed in vitro against four kinds of bacteria $\mathrm{G}(+)$ (Staphylococcus epidermidis and Staphylococcus aureus) and $\mathrm{G}(-)$ (Klebsiella and Escherichia coli). Inhibition zone diameters of the test samples are summarized in Table 8. The ruthenium(III)

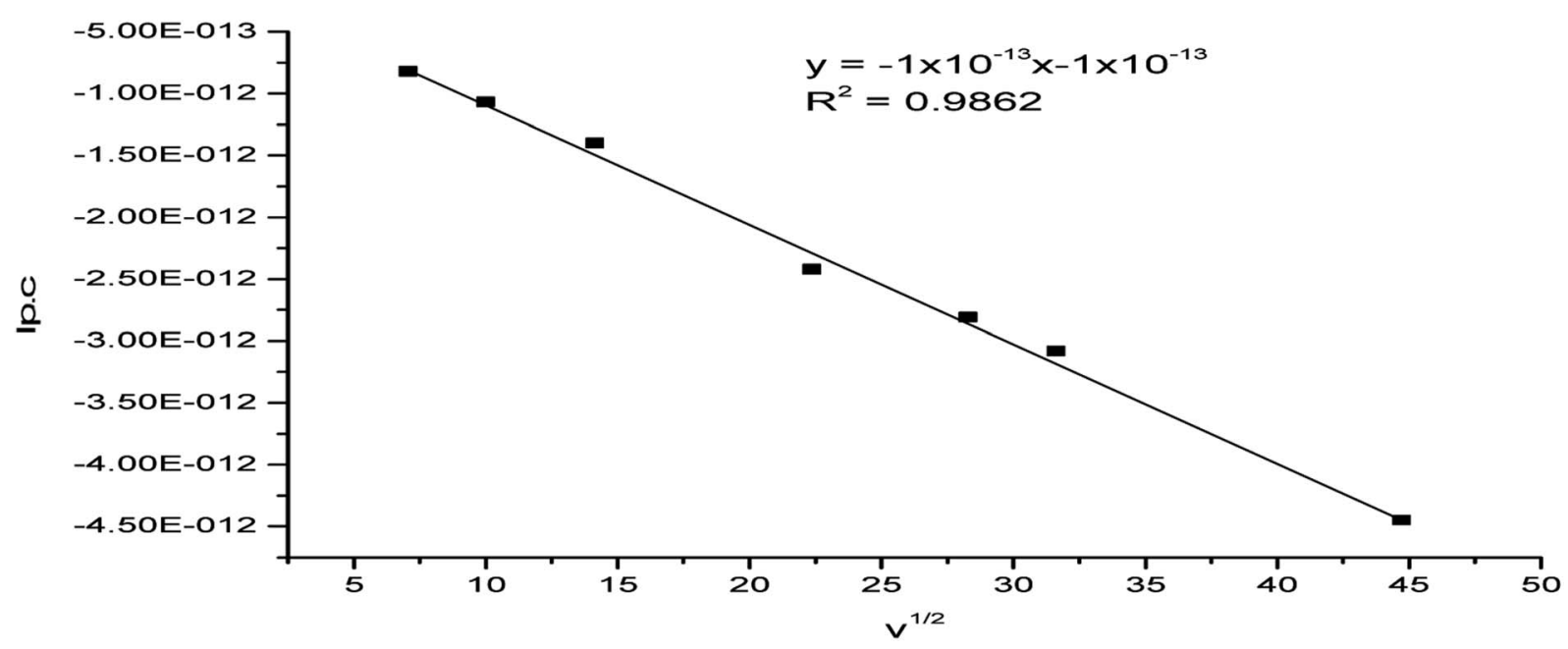

Fig. 11 Plot of $i_{\mathrm{p}, \mathrm{c}}$ Vs. the square root of the scan rate for the $\left(\operatorname{Ir}(\mathrm{Pip}-\mathrm{H})_{3}(\mathrm{Cl})_{3}\right] \cdot 6 \mathrm{H}_{2} \mathrm{O}$ complex in $(\mathrm{Bu})_{4} \mathrm{~N}^{+} \cdot \mathrm{BF}_{4}{ }^{-}-\mathrm{DMSO}$ solution at the Pt electrode vs. $\mathrm{Ag} / \mathrm{AgCl}$ reference electrode.

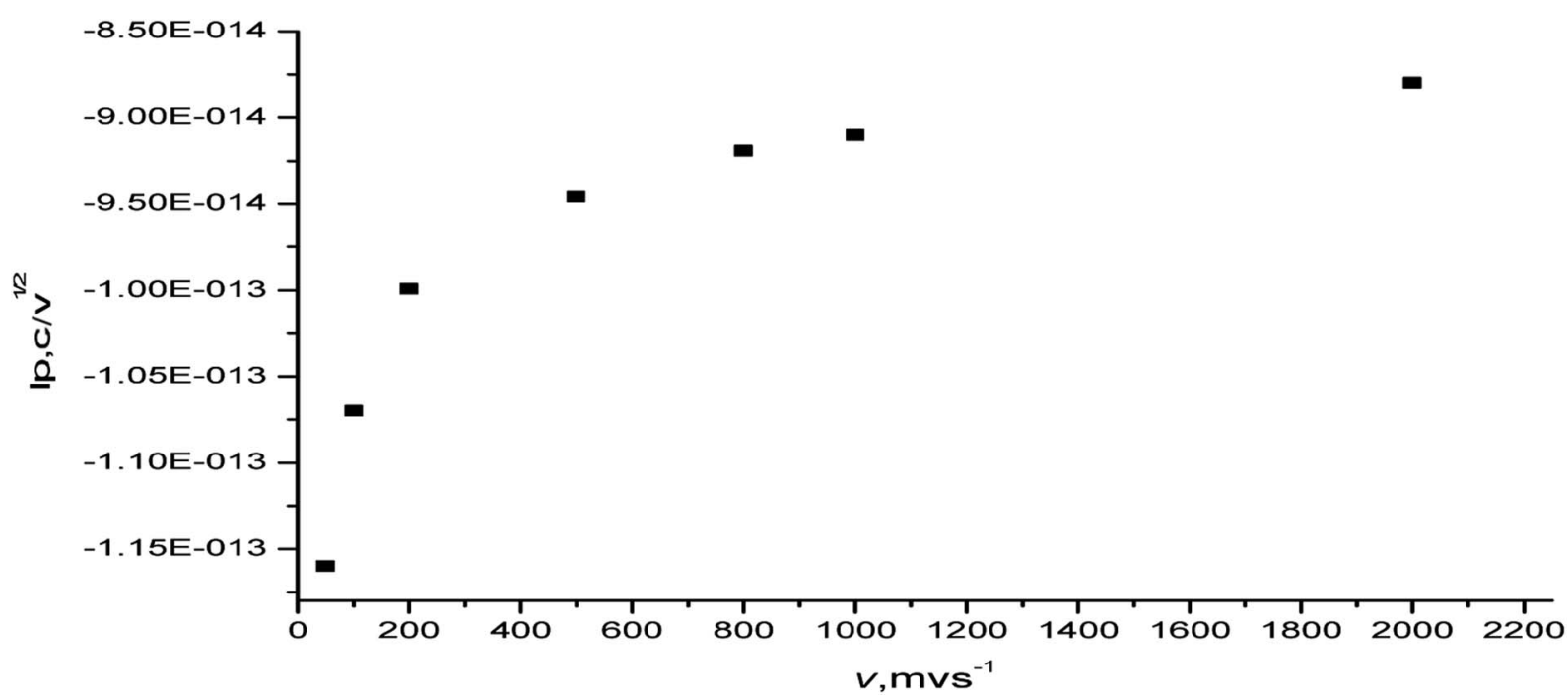

Fig. 12 Plot of current function $\left(i_{\mathrm{p}, \mathrm{c}} / \nu^{1 / 2}\right) v s$. the scan rate of the $\left[\mathrm{Ir}(\mathrm{PipH})_{3}(\mathrm{Cl})_{3}\right] \cdot 6 \mathrm{H}_{2} \mathrm{O}$ complex in $(\mathrm{Bu})_{4} \mathrm{~N}^{+} \cdot \mathrm{BF}_{4}{ }^{-}-\mathrm{DMSO}$ at the Pt electrode $v s$. Ag/ $\mathrm{AgCl}$ electrode. 
Table 8 Inhibition zone diameter ( $\mathrm{mm} \mathrm{mg}^{-1}$ sample) of (IIII, $\mathrm{Pt}^{\mathrm{IV}}$ and $\left.\mathrm{Ru}^{\mathrm{III}}\right)$ pipemidic acid complexes against some kinds of bacteria ${ }^{a}$

\begin{tabular}{|c|c|c|c|c|c|}
\hline \multirow[b]{2}{*}{ Sample } & & \multicolumn{4}{|c|}{ Inhibition zone diameter $\left(\mathrm{mm} \mathrm{mg}^{-1}\right.$ sample $)$} \\
\hline & & Klebsiella $\left(\mathrm{G}^{-}\right)$ & $\begin{array}{l}\text { Escherichia } \\
\text { coli }\left(\mathrm{G}^{-}\right)\end{array}$ & $\begin{array}{l}\text { Staphylococcus } \\
\text { epidermidis }\left(\mathrm{G}^{+}\right)\end{array}$ & $\begin{array}{l}\text { Staphylococcus } \\
\text { aureus }\left(\mathrm{G}^{+}\right)\end{array}$ \\
\hline Control: DMSO & & 0.0 & 0.0 & 0.0 & 0.0 \\
\hline \multirow[t]{2}{*}{ Standard } & Augmentin & 0.5 & 0.3 & 1.0 & 0.4 \\
\hline & Unasyn & 0.2 & 0.1 & 1.0 & 0.2 \\
\hline Ir(III) complex & & 0.5 & 0.2 & 0.0 & 0.0 \\
\hline $\operatorname{Pt}($ Iv) complex & & 0.3 & 0.0 & 0.0 & 0.0 \\
\hline $\mathrm{Ru}(\mathrm{III})$ complex & & 0.7 & 0.3 & 0.2 & 0.0 \\
\hline
\end{tabular}

Table 9 Inhibitory activities against MCF-7 cell lines for the pipemidic acid, complexes of (Ir'I, Pt ${ }^{I V}$ and $\mathrm{Ru}^{\mathrm{III}}$ ) and (doxorubicin and cisplatin) standard drugs

\begin{tabular}{llllll}
\hline & \multicolumn{5}{l}{ Viability (\%) } \\
\cline { 2 - 6 } $\begin{array}{l}\text { Sample conc. } \\
\left(\mu \mathrm{gL}^{-1}\right)\end{array}$ & Doxorubicin & Cisplatin & $\begin{array}{l}\text { Ir(III) } \\
\text { complex }\end{array}$ & $\begin{array}{l}\mathrm{Pt}(\mathrm{IV}) \\
\text { complex }\end{array}$ & $\begin{array}{l}\mathrm{Ru}(\mathrm{III}) \\
\text { complex }\end{array}$ \\
\hline 500 & 1.51 & 3.72 & 8.63 & 12.94 & 20.45 \\
250 & 2.36 & 4.98 & 16.79 & 23.18 & 32.78 \\
125 & 3.21 & 7.83 & 24.82 & 30.97 & 46.29 \\
62.5 & 5.07 & 14.68 & 39.46 & 43.52 & 71.56 \\
31.25 & 6.93 & 23.79 & 56.89 & 67.45 & 86.31 \\
15.6 & 15.46 & 34.62 & 74.04 & 82.13 & 94.20 \\
7.8 & 19.89 & 46.71 & 90.64 & 96.58 & 98.76 \\
3.9 & 24.98 & 52.85 & 98.15 & 99.71 & 100 \\
2 & 31.69 & 61.74 & 100 & 100 & 100 \\
0 & 100 & 100 & 100 & 100 & 100 \\
$\mathrm{IC}_{50}\left(\mu \mathrm{g} \mathrm{mL}^{-1}\right)$ & 0.03 & 0.5 & 1.8 & 1.2 & 5.9 \\
& & & & &
\end{tabular}

complex has a higher antibacterial efficiency than augmentin or unasyn, standard drugs against Klebsiella. Also, both iridium and platinum(rv) complexes have more antibacterial inhibition than the unasyn standard drug against Klebsiella. The $\mathrm{Ru}^{3+}$ and $\mathrm{Ir}^{3+}$ complexes have more antibacterial efficiency than the unasyn standard drug against Escherichia coli bacteria. The ruthenium(III), platinum(Iv) and iridium(III) complexes have no inhibition against Staphylococcus epidermidis or Staphylococcus aureus, comparable with the unasyn and augmentin standard drugs. The +ve charge on the metal ions is partially shared with the donation sites in the chelates and there is $\pi$-electron delocalization over the whole chelate ring. This leads to increases in the lipophilic character of the metal chelate and favors its permeation through the lipoid layers of the bacterial membranes. ${ }^{51}$ The increased activity of the metal complexes can be explained on the basis of chelation theory. ${ }^{52}$ It is known that chelation tends to make the ligand act as a more powerful and potent bactericidal agent, killing more of the bacteria than the ligand. There are other factors which also increase the activity, such as solubility, conductivity, and the bond length between the metal and the ligand, which may explain the values shown in the present case. ${ }^{53}$

\subsubsection{Anticancer assessments}

In vitro cytotoxicity assessments of the pipemidic acid complexes of $\mathrm{Ru}^{3+}, \mathrm{Pt}^{4+}$ and $\mathrm{Ir}^{3+}$ metal ions comparable with two commonly anticancer drugs (doxorubicin and cisplatin) were carried out against the human breast cancer (MCF-7) tumor cell line. The inhibitory activity data assessed based on the calculation of the inhibitory concentration $\mathrm{IC}_{50}$ are listed in Table 9. The $\mathrm{IC}_{50}$ of the platinum(Iv) complex shows that it is more effective than ruthenium(III) and iridium(III) complexes against the MCF-7 cell line.

\section{Conflicts of interest}

There are no conflicts to declare.

\section{Acknowledgements}

This work was funded by the Deanship of Scientific Research at "Princess Nourah bint Abdulrahman University", through the Research Groups Program No. RGP-1438-0001.

\section{References}

1 I. Fonseca, S. Martinex-Carrera and S. Garcia-Blanco, Acta Crystallogr., Sect. C: Cryst. Struct. Commun., 1986, 42, 16181621.

2 M. A. Toscano, A. Serrao, B. Ventimiglia, V. Colosi, M. Pennisi, R. Morgana and T. Bevilacqua, Miner. Urol., 1982, 34, 257-260.

3 S. Babić, A. J. M. Horvat, D. M. Pavlović and M. KaštelanMacan, Trends Anal. Chem., 2007, 26, 1043-1061.

4 M. Shimizu, Y. Takase, S. Nakamura, H. Katae and A. Minami, Antimicrob. Agents Chemother., 1976, 9, 569-574.

5 E. K. Efthimiadou, Y. Sanakis, N. Katsaros, A. Karaliota and G. Psomas, Polyhedron, 2007, 26, 1148-1158.

6 H. M. Refaat and D. A. N. El-Din, J. Mol. Struct., 2018, 1163, 103-113.

7 A. Barmpa, O. Frousiou, S. Kalogiannis, F. Perdih, I. Turel and G. Psomas, Polyhedron, 2018, 145, 166-175.

8 I. Turel, N. Bukovec and E. Farkas, Polyhedron, 1996, 15, 269. 
9 D. Wang and S. J. Lippard, Nat. Rev. Drug Discovery, 2005, 4, 307-320.

10 J. M. Hill, Anticancer Res., 1982, 2, 173-186.

11 M. N. Patel, H. N. Joshi and C. R. Patel, J. Chem. Sci., 2014, 126(3), 737-749.

12 A. R. Shaikh, R. Giridhar, F. Megraud and M. R. Yadav, Acta Pharm., 2009, 59, 259.

13 F. A. I. Al-Khodir and M. S. Refat, J. Pharm. Sci. Innovation, 2015, 10, 335-347.

14 A. Rusu, G. Hancu, A. C. Munteanu and V. Uivarosi, J. Organomet. Chem., 2017, 839, 19-30.

15 R. Joshi, S. K. Yadav, N. Pandey, H. Mishra, R. Tilak and S. Pokharia, J. Mol. Struct., 2018, 1167, 44-56.

16 F. A. Al-Saif, K. A. Alibrahim, J. A. Alfurhood and M. S. Refat, J. Mol. Liq., 2018, 249, 438-453.

17 P. F. Selwood, Magnetochemistry, Wiley (Interscience), N.Y., 2nd edn, 1956.

18 T. A. Yousef, G. M. Abu El-Reash and R. M. El Morshedy, J. Mol. Struct., 2013, 1045, 145.

19 M. H. Helal, S. A. El-Awdan, M. A. Salem, T. A. Abd-elaziz, Y. A. Moahamed, A. A. El-Sherif and G. A. M. Mohamed, Spectrochim. Acta, Part A, 2015, 135, 764.

20 Hyper chem. Version 7.51 Hyper cube, INC.

21 R. Gupta, R. K. Saxena, P. Chatarvedi and J. S. Virdi, J. Appl. Bacteriol., 1995, 78, 378.

22 T. Mosmann and J. Immunol, Methods, 1983, 65, 55-63.

23 S. M. Gomha, S. M. Riyadh, E. A. Mahmmoud and M. M. Elaasser, Heterocycles, 2015, 91(6), 1227-1243.

24 W. J. Geary, Coord. Chem. Rev., 1971, 7, 81.

25 E. K. Efthimiadou, N. Katsaros, A. Karaliota and G. Psomas, Inorg. Chim. Acta, 2007, 360, 4093.

26 L. Yang, W. Li, D. Tao, Y. Li and X. Yang, Synth. React. Inorg. Met.-Org. Chem., 1999, 29(8), 1585.

27 A. Beteringhe, C. Racuciu, C. Balan, E. Stoican and L. Patron, Adv. Mater. Res., 2013, 787, 236; Z. Bikadi, L. Demko and E. Hazai, Arch. Biochem. Biophys., 2007, 461, 225.

28 G. Venkatachalam, S. Maheswaran and R. Ramesh, Indian J. Chem., 2005, 44(4), 705.

29 Y. Tanabe and S. Sugano, J. Phys. Soc. Jpn., 1954, 9, 766.

30 S. Chandra, Synth. React. Inorg., Met.-Org., Nano-Met. Chem., 1992, 22(10), 1565.

31 A. B. Lever, Inorganic Electronic Spectroscopy, Elsevier, Amsterdam, 1968.
32 B. N. Figgis, Introduction to Ligand Field Theory, Interscience Publishers, New York, 1st edn, 1966, p. 287.

33 F. A. El-Saied, R. M. El-Bahnasawy, M. Abdel-Azeem and A. K. El-Sawaf, Polyhedron, 1994, 13(11), 1781.

34 D. X. West, M. S. Lockwood, A. E. Liberta, X. Chen and R. D. Willet, Transition Met. Chem., 1993, 18, 221.

35 C. Preti and G. Tosi, Transition Met. Chem., 1978, 3, 17.

36 F. Bertelli, C. Preti and G. Tosi, J. Inorg. Nucl. Chem., 1975, 37, 1421.

37 E. K. Efthimiadou, Y. Sanakis, N. Katsaros, A. Karaliota and G. Psomas, Polyhedron, 2007, 26, 1148.

38 M. Badea, R. Olar, D. Marinescu, V. Uivarosi, T. O. Nicolescu and D. Iacob, J. Therm. Anal. Calorim., 2010, 99, 829.

39 E. S. Freeman and B. Carroll, J. Phys. Chem., 1958, 62, 91.

40 H. H. Horowitz and G. Metzger, Anal. Chem., 1963, 35, 1464. 41 A. W. Coats and J. P. Redfern, Nature, 1964, 201, 68.

42 B. D. Cullity, Elements of X-ray Diffraction, Addison-Wesley, Reading, MA, 1972, p. 102.

43 M. Salavati-Niasari, F. Mohandes, F. Davar, M. Mazaheri, M. Monemzadeh and N. Yavarinia, Inorg. Chim. Acta, 2009, 362(10), 3691.

44 S. Velumani, X. Mathew and P. J. Sebastian, Sol. Energy Mater. Sol. Cells, 2003, 76, 359.

45 J. P. Singh, T. Karabacak, P. Morrow, S. Pimanpang, T.-M. Lu and G.-C. Wang, J. Nanosci. Nanotechnol., 2007, 7, 2192.

46 S. Krehula and S. Musić, Croat. Chem. Acta, 2011, 84(4), 465. 47 T. Zhang, S.-C. Li, W. Zhu, J. Ke, J.-W. Yu, Z.-P. Zhang, L.-X. Dai, J. Gu and Y.-W. Zhang, Surf. Sci., 2016, 648, 319.

48 B. S. Parajon-Costa, A. C. Gonzalez-Baro and E. J. Baran, Z. Anorg. Allg. Chem., 2002, 628, 1419.

49 M. L. P. Santos, I. A. Bagatin, E. M. Pereira and A. M. D. Ferreira, J. Chem. J. Chem. Soc., Dalton Trans., 2001, 6, 838.

50 A. J. Bard and L. R. Faulkner, Electrochemical Methods: Fundamentals and Applications, Wiley, New York, 2nd edn, 2001.

51 Z. Chohan and S. Mushtaq, Pak. J. Pharm. Sci., 2000, 13(1), 21-27.

52 S. K. Sengupta, O. P. Pandey, B. K. Srivastava and V. K. Sharma, Transition Met. Chem., 1998, 23(4), 349-353.

53 S. Chandra, S. Raizada, M. Tyagi and A. Gautam, Bioinorg. Chem. Appl., 2007, (1), 51483. 